\title{
REBUILDING THE DEMOCRACY OF THE TAXPAYER ${ }^{1}$
}

\author{
Konstantin Yanovskiy \\ Head of Institutional Development Department \\ Gaidar Institute for Economic Policy Moscow, Russia \\ Sergey Shulgin \\ Senior Research Fellow \\ Russian Presidential Academy of National Economy and Public Administration \\ Ilia Zatcovetzky \\ Research Fellow \\ Samuel Neaman Institute for Advanced Studies in Science and Technology, \\ Technion (Israel)
}

Sergei Zhavoronkov

Senior fellow Gaidar Institute for Economic Policy

Moscow, Russia

The voter - bureaucrat is locked into a situation of a conflict of interests: as a conscientious citizen, he or she should support optimal expenditure levels for providing certain public goods, but as a person whose wellbeing and career depend on the volume of expenditures for providing public goods, he or she is interested in supporting volumes and prices which obviously exceed the levels acceptable for most citizens of the state. The bureaucrat is also interested in obtaining excess control and regulatory empowerment and authorization. It follows that a conscientious and enlightened functionary should submit a statement about a conflict of interests, and abstain from voting until retirement or demotion.

A large and growing group of voters is made up of "professional" recipients of aid. It follows that persons, whose interests include the redistribution of resources of the taxpayers in their own favor, also have no moral right to make decisions by voting during elections.

This applies in part also to those entrepreneurs who derive most of their income from the budget.

\footnotetext{
${ }^{1}$ The paper presented is the 13-th chapter of the book "How the Import of Modern Western Institutions Suppresses Economic Growth: 1990-ties East-West and West-East Transition" (in Russian original: "Institucionalnye ogranichenia sovremenogo ekonomicheskogo rosta" - Institutional Constraints on Modern Economic Growth - "Delo" Publishing House Moscow, 2011). The book is in translation currently. See the book structure and the chapters' content short description.
} 
Another grounding factor is the historical statistics of state budget balancing (the dynamics of state debt) and inflation (see Appendix 4: The History of Inflation and Budgetary Deficit after the Introduction of Universal Suffrage). In the age before universal suffrage, problems of financing were almost always an outcome of military cataclysms or other external shocks of a similar magnitude. In the age of universal suffrage, budgetary deficit, growing state debt, and inflation have become the norm.

Keywords: Universal suffrage, conflict of interest, taxpayers' democracy, pure and mixed public goods

JEL codes: D72, D73, H41, N40, P16

Dutch taxes are approved by two-thirds of the population, and only one-third are dissatisfied: those who work. Dutch taxpayers' saying

In Israel, one-third of the citizens pay taxes, one-third serve in the military, and one-third do the collecting.

The problem is that this is all the same one-third. Saying of Israeli taxpaying voters liable for military service

One man with a plough, seven hold out their spoons.

Empirical law for evaluating the taxpayer's share in a country with a welfare state tradition of much longer standing than in Denmark or in Israel

In places where it is meaningfully abided by (the democratic states), the principle of universal suffrage engenders a multitude of stimuli for non-cooperative (opportunistic) behavior.

The voter bureaucrat finds him or herself in a situation of a conflict of interests: as a dutiful citizen, he or she should support an optimal spending level for providing certain public goods. As an individual whose wellbeing and career depend on the spending total for providing public goods, he or she is interested in the establishment of both the volume and the cost a priori exceeding the level optimal for most citizens. He or she is also interested in obtaining excess regulation authority. Consequently, the dutiful and enlightened official should make a statement about a conflict of interests and abstain from voting until retirement. 
A large and growing group of voters is made up of "professional" recipients of aid. Among them there are more and more individuals who have never had independent income earned by providing goods or services evaluated by the market. A sizeable group is in many countries made up of immigrants arriving with the express objective of receiving such aid. Consequently, persons whose interest is bound up with the redistribution of resources from taxpayers for their own benefit, also have no moral right to make decisions by voting in elections.

The same applies in part to entrepreneurs obtaining their principal income from the budget, for instance, through an extraordinarily fortunate sequence of tenders won for providing goods and services for state needs.

Mass media workers and education systems interested in financing both reliable and independent of quality of the work performed, demand budgetary financing for themselves (or else defend such financing). They have the full right to defend their position publicly, but their right to foist their position on donors by force - by means of voting - is also doubtful.

The sum total of the agents described (and the list is far from complete) tends to force - "in the name of the public good," obviously - the donor taxpayers to pay for their existence without need. ${ }^{2}$ Besides, it tends to extinguish attacks in the form of pangs of conscience (by aiding both those genuinely in need and those who have themselves contributed to the creation of their dire condition: the reasons for such generosity are easily explained both by the source - the money of others, and the interest - to widen the coalition of recipients of aid and mixed public goods).

Thinking back to the universal and eternally relevant recipe for flourishing as given by Adam Smith - not overly burdensome taxation and reasonable laws (limited intervention $)^{3}$ - we are compelled to affirm the following. Universal suffrage gives the officials and the aid recipients interested in expanding expenses the right to receive income by using the state apparatus to full capacity. It thereby creates an instrument for

\footnotetext{
${ }^{2}$ The absence of such a coalition as a significant player is granted in a non-evident way in models and experiments by V. Smith (1980) in financing public goods. In other words, the 2002 Nobel Prize Winner supposes that taxpayers are capable of evolving a private mechanism, an agreement, in accordance with which it will provide financing even for pure public goods. Our suggestions do not go this far at present.

3 "Little else is requisite to carry a state to the highest degree of opulence from the lowest barbarism, but peace, easy taxes, and a tolerable administration of justice; all the rest being brought about by the natural course of things " Lecture in 1755, quoted in Dugald Stewart, Account Of The Life And Writings Of Adam Smith LLD, Section IV, 25. http://www.econlib.org/library/Smith/smWN0.html . See also Adam Smith, The Wealth of Nations, Chapter V of Book IV.
} 
shooting up taxes and state expenditures. In an age of universal suffrage the volume of mixed public goods provided by the state rises sharply.

By contrast, in an age of classical liberalism, the connection between payment of taxes and the right to be represented in parliament seemed self-evident. Thus, the same Adam Smith suggested establishing a quota for the colonies as a way to resolve the conflict with them: the colonies would be represented in England's Parliament based on their participation in general taxes. ${ }^{4}$ Quotas also became the preponderant motivating factor in the voting rights reforms in Great Britain (1832 and 1867).

The growing burden imposed upon budget donors leads to a slowdown in economic growth rates essentially achievable under conditions of Rule of Law democracy.

An easy-to-follow example of the consequences implied by giving up the democracy of the taxpayer is provided by the historical statistics of state budget balancing (the dynamics of state debt) and inflation (see Appendices I and II to the Third Volume). During the age preceding universal suffrage, financing problems were almost exclusively connected with military shocks or other upheavals of similar magnitude originating from the without. In an era of universal suffrage, the budget deficit, growing state debt, and inflation have become the norm.

In recent years, economists and political scientists have once again begun to focus on the influence which the institution of universal suffrage has on the economy; on the problem of the genesis of this institution; and on discussions which preceded its introduction into society.

Let us note a bare few of the principal positions discussed in this connection.

1. Introducing universal suffrage has led to drastic growth in state expenditures (Aidt, Dutta, Loukoianova 2006; Funk, Gathmann 2006; Tavares, Wacziarg 2001); the last of these papers provides argumentation in favor of the conclusion that modern democracy in general has a negative impact on economic growth. ${ }^{5}$

\footnotetext{
${ }^{4}$ See ibid.

5 True enough, based on data from 1950-90, Przeworski (Przeworski et al., 2000) reaches somewhat more optimistic conclusions. The outcomes of the two studies do not contradict each other in principle. The present paper deals with a different and shorter period: 1970-89, working with more detailed specifications of channels of influence upon growth. Magnitude of state consumption is among influence channels of this kind, having an obvious and significant impact upon growth rates. At the same time, magnitude of state consumption is positively and statistically bound up with democracy in a significant way (see Table 10 on p. 1371).
} 
2. Growth of state expenditures took place thanks to redistribution programs and programs for providing "mixed" public goods (education, health, and, to a lesser extent, projects in infrastructure, science, culture, and so on).

3. Introducing universal suffrage worsened the condition of safeguards of private property (Acemoglu, Robinson 2006), just as had been feared by the conservative-minded Founding Fathers (Madison, The Federalist №10), albeit without destroying them entirely in the short term, as Karl Marx had hoped (for the appropriate survey, see also Przeworski 2010, pp. 80-84). In his essay on "The Law," Bastiat presents universal suffrage as one of the ways to introduce "legal plunder" (pp. 6-7).

4. Introducing universal suffrage lowers the quality level of the voter, making voters on average considerably more dependent, less educated, less experienced in life, and so on; a universal property qualifying requirement or a tax-related one does not deprive anyone of the right to take part in elections, but rather creates an additional stimulus to achieve economic self-sufficiency (Przeworski, 2010, p.75).

Przeworski makes the statement cautiously, while Acemoglu and Robinson make the statement categorically to the effect that no real alternative to universal suffrage is available. This is the case insofar as the population groups which had been historically denied suffrage sought and achieved the annulment of voter qualifying requirements. But in a different paper, the selfsame Przeworski shows that the right to vote was in many cases in a transparent fashion "bequeathed" by the powers that be upon voters, rather than won by groups previously denied representation in government.

Analyzing the instances cited in Acemoglu-Robinson, we could have only extended this list (as we will in fact proceed to do in what follows).

It is evident that, apart from the 1770s in the North American colonies and the 1830s in Northern England and Scotland, when well organized, wealthy, and armed groups (or else groups easily capable of arming themselves) fought for representation in Parliament, it is difficult to come up with clear instances of tactics of conquest resorted to in order to obtain voting rights. 
In all other cases, weapons in the guise of the right to vote were handed over to relatively weak population groups, making them strong (as Przeworski 2010, p.80, notes; see also the results of statistical analysis and data on leftist parties' success in elections in Appendices 1 and 2 to the present chapter).

The present book focuses attention on the following problems of universal suffrage:

1. Moral corruption of the budget-dependent voter (whose contribution to the total budget is smaller than his or her income from the same budget), conflict of interests of those able to use their voting ballot to pressure other taxpayers to continue or even to increase payments in their favor;

2. Lowering of the quality of supply of pure public goods (defense provides an example) concomitant with growth of commitments to provide mixed public goods (redistribution, health and medical care, education, and so on; for further detail, see Appendix 1 to the present chapter ${ }^{6}$ );

3. Reproduction of financial problems - budgetary deficit, growing state debt, inflation, and, in some cases, defaulting on debt payment as a result of pressure by pro-spending coalitions without due balancing counter-pressure by anti-spending ones (for more detail, see Appendix 2 to the present chapter).

\section{Genesis of Rule of Law Democracy}

\section{Historical Conditions of the Gestation of the First Rule of Law Democracies}

Institutes of modern Rule of Law democracy did not take shape in the course of academic discussion, nor did they emerge as a result of processes of negotiations. The first of the Rule of Law states currently in existence, those maintaining substantial political competition, independent courts and press - these include the Netherlands, Great Britain, Sweden, Switzerland, and the United States - emerged as a result of bloody wars and revolutions. The institutions in question emerged based on the outcomes of wars:

\footnotetext{
${ }^{6}$ See also "The Gender Role of the Government: Some Explanations of Family Crisis" working paper for some cases and for statistical analysis: http://papers.ssrn.com/sol3/papers.cfm?abstract_id=2236328
} 
Civil wars (Sweden, Switzerland, Great Britain, France, the US);

Against external foes (the Netherlands, Switzerland, the US).

In most states of this type, political competition mechanisms took shape within the voter qualifying requirement type of democracy of the taxpayer (this is most vividly evidenced in the American colonies' struggle for representation, as well as in the Great Reform of 1832 in England a generation later, when the reform was introduced as a result of pressure by the industrial regions). In many of the oldest democracies listed, strong Protestant tradition played a significant role in key decision making (in particular, concerning the dethronement of monarchs whose authority had long been considered divinely sanctioned. This last did, however, imply - in accordance with Biblical tradition - fulfilling the condition of complying with the obligation of protecting the citizens from danger. Refusing the obligation was taken as tantamount to refusing the royal mission and the conditions of anointment to the throne; thus the Netherlands, Great Britain, and the United States).

\section{Equating Democracy with the Modern Version of a "Welfare State" Where Universal Suffrage Is in Effect}

\section{Dahl and Tilly: Democracy and Its Genesis}

According to the definition given in Robert Dahl (Dahl 2000), democracy is a means of government characterized by the following signs: universal "effective" participation, "understanding" based on a condition of being well informed, implementation of control of the daily agenda, and "involvement in the life of society." This complex notion, which hardly lends itself to formalization, is nonetheless extremely popular among humanities scholars and state employees in Western countries.

Charles Tilly (Tilly $2007^{7}$ ) uses a similar approach to arrive at a definition (by listing signs or requirements). Tilly refers to an organization which for many years running has been monitoring political regimes; the organization is Freedom House (FH, USA). In order to define a country's political system as a democracy, the organization's experts attempt to determine the availability of the following in the country in question ${ }^{8}$ : political party competition, universal suffrage for all adult citizens, regular elections, access of the main parties to the mass media.

\footnotetext{
${ }^{7}$ Pp. 16-18.

${ }^{8}$ http://www.freedomhouse.org/
} 
It should be noted that the requirement of "universal suffrage for all adult citizens" has an obvious and yet doubtful grounding. The most extended periods of democratic development and nearly all of the democratic tradition, beginning with antiquity, turns out to be as if severed from the concept of "democracy." That is, if this approach is consistently relied upon, democracy has no roots stretching back into antiquity - unlike what was believed by, for instance, the Founding Fathers of the US Constitution. Besides, these same Founding Fathers themselves then turn out to be "excommunicated from democracy," as well.

True enough, R. Dahl agrees that democracy is a historically conditioned notion (thus acknowledging the US and Great Britain of the $19^{\text {th }}$ century as relatively democratic countries). However, he sees it as a notion traceable to its highest forms, in which a genuine must was the availability of both universal suffrage for all adult residents of the country and - what is significant - separation of power centers, distribution of authority, or "Polyarchy."

Dahl also notes that democracy emerges given certain conditions, posing the question about just what these conditions may be. He offers the hypothesis that a historical precondition of democracy is a split within the elite, which leads to the development of the "habit of looking for mutual guarantees" among the "bandits." (Dahl, .. 1972) ${ }^{9}$ The author argues that such an evolutionary path is closed to modern states. He notes - with ample justification - that lesser opportunities for the authorities physically to destroy the opposition stimulate coerced toleration of the existence of opposition as such.

At the same time, Dahl claims that property relations play no role in these issues. This in view of the fact that the founders and the defenders of old Rule of Law democracies (the Netherlands, Great Britain, USA, ${ }^{10}$ and others) were mostly people of middle or upper income class level, who were also interested in protecting property. Questions of property (concern about the king's intention to violate the agreement with Cromwell's generals about the restoration and about the protection and acknowledgement of property rights) played an important role in the Glorious Revolution, as well.

Dahl does not deny - but he does underestimate, and, in our view, almost ignores - the role of violence in the emergence of the first Rule of Law democracies. By

\footnotetext{
${ }^{9}$ P.38.

${ }^{10}$ See, for instance, The Federalist and its authors' unambiguous position concerning the question of defending property, in №№10, 51, 52, as well as the assessment of the situation made by Beard, a historian (Beard, 1962), and by his opponent (McDonald, 1958). The leading American historian Richard Pipes (whose predictions, unlike those made by most of his colleagues, tended to come true) is of the same opinion. See Pipes 2000, pp. 49-59, 197-200.
} 
contrast, Tilly directly indicates violence as a source of the "categorical inequality" which interferes with democratic progress.

At the same time, the genesis of many of the first Rule of Law democracies was accompanied either by national wars (for independence), or else by civil war. In addition, France went to war in order to achieve hegemony in Europe.

Problems of lack of consensus concerning basic values were resolved by means of deportation or voluntary emigration of the losers, to say nothing of death as a result of the wars occasioned by the conflict (e.g., Catholics in the Netherlands, Catholics and monarchists in England, loyalists in the US).

\section{Redistribution as a criterion of "level of democracy"}

In a paper (Boix 2001) devoted to explaining national distinctive features in "public sector" (state sector) shares of the GDP, Charles Boix, a member of the faculty at the University of Chicago, singles out differences between "democratic" states, or democracies with a low share of participation by adult citizens in elections, and "authoritarian" countries. For his own part, the author ${ }^{12}$ (Boix 2001, p. 4) sees no essential difference between authoritarian countries and countries with a competitionbased democracy but lacking universal suffrage. ${ }^{13}$ Insofar as not a single voter qualifying requirement democracy (that is, no democracy of the taxpayer) is on record during the period under consideration, 1950-1990, differences among democracies are determined by activeness during elections, including activity of poor citizens dependent on the budget.

With reference to the results obtained by Boix (countries with low electoral activeness have the most compact state; an authoritarian state is considerably more burdensome for the taxpayer, even though it, too, lags behind universal suffrage democracies with a high share of voters; see Ill. 13.1.)

\footnotetext{
${ }^{11}$ With change in authority as a result of elections, as well as with the share of participation in elections attainable provided universal suffrage is in effect and voter activeness is high.

${ }^{12}$ As opposed to the methodology of A. Przworski's group, which he uses in part (Przeworski et al. 2000; Alvarez, Cheibub, Limongi, and Przeworski 1996). For our methodological principles, see Appendix 2 to Volume 1.

13 "Assuming that authoritarian regimes exclude the poorest from the policy-making process, the median voter in a nondemocratic system is richer than the median voter in a full democracy." The author confuses the notions of authoritarianism, some mysterious "nondemocratic system," and democracy involving a voter qualifying requirement. It is clear enough that under authoritarianism, "voters" or "electors" are a fiction, just as are elections, even if an imitation of such a proceeding is in fact staged. And yet in the USSR, where elections were imitated throughout a historically extended period, Soviet "voters" were on average much poorer than the "median voter" in "a full democracy."
} 
A British colleague of Boix' (Hall 2010) interpreted the results obtained (Boix 2001, p. 10) in a more determinate manner, specifically reading them as a demonstration of the advantages of the state which provides for everyone "from cradle to grave." As it turns out, such a state also raises the likelihood of democratic development of society. And indeed, if democracy is identified with universal suffrage democracy, such a conclusion appears to be not devoid of sense.

\section{Share of state spending in GDP,\%}

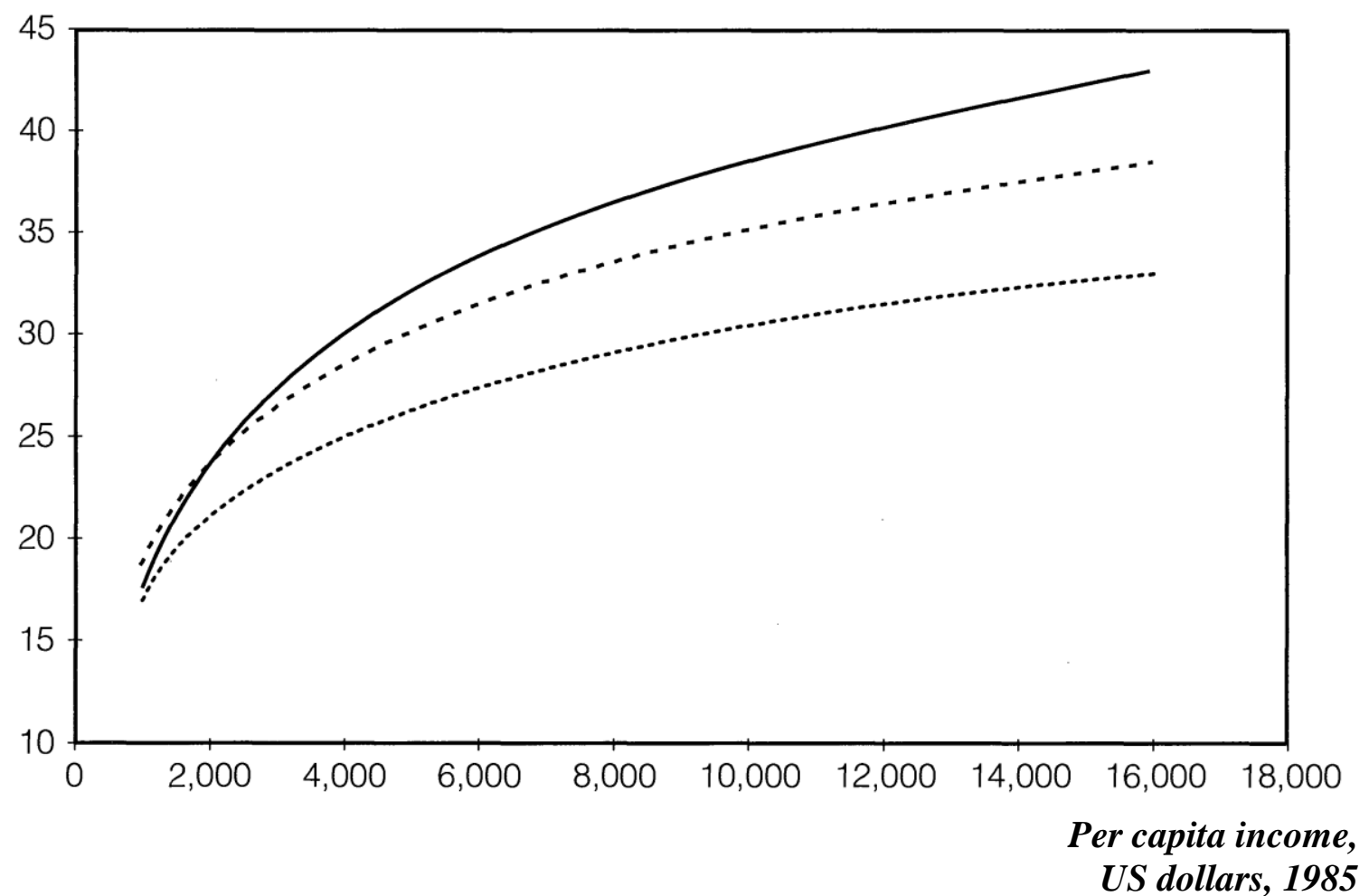

Illustration 13.1. Participation in elections as a factor in the size of the "public sector." Source: Boix 2001, fig. 2.p.10

\section{Douglas North: “Open Access Orders”}

Douglas North believes that even technical and military technical evolution in Europe contributed to the formation of new institutions. The rising cost of armies required spending which was unmanageable for many courts, thus conditioning the "sale" of rights and privileges to the representatives of well-to-do citizens. That is, it led to the emergence of the first parliaments (North 2005, pp. 131-132). 
North makes a point of focusing on the role and the problem of violence in his study of violence and social management (North, Wallace, and Weingast 2011). In this study, North introduces a model in which the state is consolidated as a long-term dynamic coalition of the strongest players (military leaders, field commanders) for the purpose of extracting revenue payments and avoiding the costs of permanent coercion.

In the same study, North and his colleagues take their departure from the notion of democracy shaped by Dahl's work (pp.438-439). From among the features of Rule of Law democracy (in the book it - in the most general sense, including formally nonpolitical public structures - is called a society of open access, or Open Access Orders), they single out the ideology of equality and universal participation, as well as the state's monopoly on violence. Apparently, self-defense, the $2^{\text {nd }}$ Amendment concerning the right to bear arms, "civil arrest," and other phenomena and institutions important for the defense of rights and dignity of the individual person, are something the authors do not consider crucial, unlike the right to institute corporate societies and to disseminate (sell) their stock among unspecified groups of people.

In connection with the "widely accepted set of convictions concerning inclusion and equality of all citizens," $" 14$ the term "inclusion" immediately reminds us of the wellknown American non-government organization "Acorn"15 and the radical leftist agenda. More precisely, it makes us think of the "must" of maximally expanded "inclusion" of professional recipients of social goods in the process of suppressing the taxpayers by the bureaucrats.

\section{Acemoglu-Robinson on Genesis of Universal Suffrage}

History, as per G. Buchanan's phrase, is "the only laboratory available to the economist." D. Acemoglu and G. Robinson probably more often than other famous (often cited) American economists evince a penchant for working in this "lab." (Acemoglu, Robinson 2006) Below we will devote some attention to one of the attempts undertaken by them to provide a formal description of complex political-economic processes.

\footnotetext{
${ }^{14}$ For a description of the features of "Open Access," see North, Wallace, and Weingast 2011, p. 114.

15 http://www.acorn.org/: on November 2, 2010, the organization's site ran the report about submission of a bankruptcy claim after cessation of financing by the state. The organization's 40 -year-long activities are drawing to a close, and the site may discontinue its work.
} 
To describe the process of the emergence of modern democracy, these authors suggest the following model of transition to universal suffrage.

Society consists of the wealthy, the middle class, and the poor. At the outset, the wealthy rule. The poor are not content with their poverty and wish to deprive the wealthy of part of their belongings. The wealthy are not concerned about this as long as the poor present no grounded threat of revolution. Then the wealthy, realizing the seriousness of the threat, offer the poor a certain ransom. The wealthy promise to pay it more or less regularly in return for that the poor should give up revolutionary ideas. Understanding that they can provoke fear in the wealthy, the poor will not wish to rest content with the ransom, insofar as they have no guarantee that the tribute will be paid in the future.

In order to ensure payments, none other than universal suffrage is required. Universal suffrage is precisely the instrument which facilitates taking money away from the rich and dividing it among the not rich on a regular basis. True enough, upon running into such a remarkable democracy, the wealthy may initiate an upheaval, or else try to prevent or put down the revolution by means of repression.

Depending on gains expected by the poor from democracy (the piece of the national pie redistributed by means of progressive taxation) and in view of the costs of revolution (costs of personal participation, losses from destruction of property in the course of revolution), either democracy triumphs and grows stronger, or a dictatorship is introduced; alternatively, society finds itself in a condition of unstable balance with regular upheavals and revolutions. When decisions are made concerning turning power over to others, the wealthy have some choice, after figuring in the factors enumerated and their costs, risks of upheaval and repressions (after upheavals or for the purpose of putting down revolutions).

Based on this line of reasoning, the authors offer a model involving approximately twenty variables. But rather than analyze this model, we will ask the question about...

\section{What was the nature of the real historical process described by the model?}

Historically, the perpetrators of revolutions are, as a rule, not the poorest of people. This is particularly true of the history of England. It is no accident that the only reform preceded by disturbances of a magnitude which gave the authorities a sense of real danger was the Great Reform of 1832. At this time, the right to vote was obtained by taxpayers who satisfied a relatively high voter qualifying requirement; these were just a 
bare few percent of the most well-to-do people in the country. Neither the Charter movement, nor any other campaign of mass protest had any distinguishable impact. They are all evidently unconnected with the reforms of 1867 and 1884-85. The supposition that previous to the reform of 1918, women home owners were the real force casting the fear of revolution upon those in power looks simply comical. The ability of less wealthy women, who achieved the right to vote in 1928, "to shake the foundations of the regime" is even less real (Table 13.1).

In countries where revolutions opened the way to the construction of institutions favorable to economic growth, people initiated revolutions in order to provide guarantees of property rights and against fines and levies, but not in favor of levying tributes from others. The redistributing initiative is more often carried out bureaucratically and in tranquility, rather than by revolutionary means.

The authors also acknowledge that the situation is more stable if the constitution limits the ways open to the indigent majority to rob the elite. At the same time, they cite Charles Beard (Beard 1913), who claims that constitutional protection of property rights in the US is the result of steps undertaken by the wealthy elite. ${ }^{16}$

In the eighth chapter of their book, Acemoglu and Robinson note the role played by political competition in extending the right to vote. But they do not take into account the existence of influential groups of bureaucrats. These last are interested in universal suffrage. Such an interest on the part of the bureaucracy is prompted by the prospect of including a "manageable" electorate in the body of voters. An electorate of this kind has a source of income in the budget and is almost guaranteed to vote for expanding budgetary spending.

The classic division into "rich," "middle class," and "poor" used in the model weakens it. The rich and the middle class are no monolith. Among the rich there are

\footnotetext{
${ }^{16}$ In this connection, the model should be mentioned which shows the "non-emergence" of property rights (Polishchuk, Savvateev 2004). This is supposed to be the case in the wake of the preference of the politically influential wealthy not to establish any unambiguous limits of property. Acemoglu and Robinson do not consider this model. We for our part will note that such a possibility emerges when success and joining the elite depend almost exclusively on forging the right relationship with those in power. Success in attracting consumers' sympathies (especially of the long-term kind) in Russia of the 1990s - precisely the conditions described by the "non-emergence of rights" model - played no significant part in determining one's chances of becoming part of the elite. But such a possibility of both becoming a part of the elite and "taking over the state," exploitation for their own purposes, played no part in England of the $19^{\text {th }}$ century. Such a takeover took place in real history when civil unqualified budget recipients were in power, and able to determine the outcome of elections by their majority (of countries described by Acemoglu and Robinson, a comparable situation is realistically reproduced in Latin America). Domination of the electorate made up of aid recipients evidently presents better opportunities for such a takeover and subsequent use of power against rivals which are more effective than when budget donors are in power. This, in fact, is one of the important lessons to be learned from Russia's democratic experience of the 1990s.)
} 
leaders, but there are also outsiders. Given high competition, the overwhelming majority can become outsiders. A leader can become an outsider (G. Ford); this is all the more probable when competition is high. Even a leader can act in accord with the accepted ideology, or with an ideology foisted upon him or her (financier G. Morgan, who supported state control under T. Roosevelt, even though such control was in advance known to be deleterious to Morgan's own interests). Some of the leaders in modern business make their living off the peculiar features of the economy which have to do with state interference (G. Soros).

Before going on with the discussion of the conditions and factors impacting the genesis of the institution of universal suffrage, which is often identified with democracy as such (Dahl 2000; Freedom House 2009), let us try to ask this question: what is democracy from the point of view of the rational subject maximizing his or her utility? In other words, what features of democracy can be useful in providing for the conditions of economic growth?

\section{Economic-Normative Approach to Democracy}

What requirements must a political regime meet in order best to protect property rights and least to threaten property owners?

M. Olson claimed that such qualities are features specifically of a democratic state. Olson put forth the suggestion that any coalition receiving the majority vote in democratic elections, promotes interests which are more reflective of the interests of the minority than would be the case with an autocratic regime (Olson 2000). On the one hand, in favor of such a suggestion is the fact that in most democratic countries, all large parties (that is, at every moment both the ruling party and the opposition) enjoy the support of some part of the entrepreneurs. Thus, according to a study by the Gallup Organization, no statistically reliable connection was to be observed in the 2008 elections between income level and voting for B. Obama or J. McCain (Gallup 2008). In these elections, the wealthy voters could even with greater likelihood have voted for a semisocialistic candidate, rather than for the "centrist" McCain. On the other hand, the choice of object of support is not always determined by purely material interests of the entrepreneur, especially if this last is certain that personal ties with the winner will help avoid unpleasant consequences of the measures being offered, which will be damaging to business. 
Finally, the business elite can become thoroughly ingrown in the political class (Japan prior to defeat during World War II, Indonesia under Soeharto, and contemporary Israel, where the rich usually vote for socialists and the poor root in favor of parties introducing market reforms). Normal stimuli of healthy business are perfectly uncharacteristic of such entrepreneurs ("as long as we are under control, we will never go bankrupt"). Even in Great Britain, after a near-seven-decade-long period of socialistic experimenting, Thatcher ran into what was, to put it mildly, a cool attitude toward her reforms on the part of most large businesses (Peregudov 1996).

Democratic regimes have an important advantage - possibly, a decisive one - in competition when it comes to providing the conditions necessary for long-term economic growth. As we have already noted a number of times, nearly all economists agree with the view that securely guaranteed property rights are beneficial for economic growth. At the same time, it is evident that an entire series of threats endangers these rights and their guarantees, stemming from both private persons and from the state (including the case of the state's being "taken over" by interest groups, that is, by small-sized coalitions of private persons).

Competitive democracy obviously weakens the opportunities for any leader or group to derive administrative-political revenue from his charges. Free mass media and a powerful, rigid opposition will not take long in delivering a blow against any group of hunters for others' goods. The very next elections will almost inexorably bring retribution.

Curiously enough, even R. Dahl, who claims that his term "polyarchic democracy" applies only to democracy with universal suffrage, "exposes himself" in the scenario involving political competition. It is absolutely clear that in order to provide high competition on the political "market" - as well as on the media market (that is, polyarchicness in the literal sense of the word), there is no need for universal suffrage: conflicts among interests of various groups of property owning voters suffice.

The same applies to the provision of optimal conditions for the emergence of the mechanism of the authority of the law.

If we take into consideration that whatever the population size, a part of the population always remains who almost never vote, the ideal of universal suffrage realized in practice is, even if attainable, then attainable only by means of coercive (compulsory) voting - something that does, in fact, exist in a series of states (for instance, in Belgium). 
But even in these countries, where non-participation is punishable by a fine, voter turnout never reaches $100 \%$.

In a series of cases, the "non-showers" turn out to be the poorest strata of the population; they take no interest in politics due to being overburdened with daily concerns. In some cases, the same group may include the middle class and the wealthy, as well, if their participation turns out to be meaningless in the interim between elections (failing to provide a real taking into account of their interests).

At the same time, strictly speaking, no feasible voter qualifying requirement destroys universality provided any citizen not shirking "persistent work" is capable of meeting it. This is precisely the situation which began to take shape in England after the voting reforms of 1832 .

\section{Transition from Democracy of the Taxpayer to Universal Suffrage and Some of the Consequences}

\section{Party Competition for New Groups of Voters}

To sum up: Acemoglu and Robinson mention (along with their model, but as being of secondary importance) the scenario of Tory-Whig competition, conservatives and liberals, vying with each other for new groups of voters. This competition is something the two authors see as one of the reasons for the gradual (but clearly not the most important) expansion of the voting population.

At the same time, reforms in voting legislation need to be distinguished from each other. The reform of 1832 was fundamental, establishing a correspondence between the unwritten constitutional standard of «taxation = representation» and the suffrage standard. The reform of 1867 was private, expanding the group of taxpayers represented in Parliament while taking into consideration the realities of the new period when these new groups began to make growingly more noticeable contributions to the income part of the budget.

The reform of 1884-1885 extended the group of voters to include all adult males, while remaining generally true to the same logic of expanding the group of taxpayers. It for the first time constituted a clear violation of the principle of representing only taxpayers. 
The reform of 1918 gave the right to vote to women owners of real estate, aged 30 and older. In 1922, these violations of the principle, though mitigated by the universal draft of the men during World War I, were compensated for by university districts and "business votes." Both new pieces of legislation increased the representation of property owners in opposition to the ochlocratic tendency of suffrage development (in 1928, all adult women were given the right to vote). Both pieces of legislation were annulled by the Laborites in 1948.

Table 13.1

Electoral Response to Some of the Reforms of the $19^{\text {th }}-20^{\text {th }}$ Centuries in England

\begin{tabular}{|c|c|c|c|}
\hline \# & Event (Reforn & $\begin{array}{l}\text { Party in Power (Party } \\
\text { Introducing the Reform) }\end{array}$ & $\begin{array}{c}\text { "Electoral Response" (Results of Soone: } \\
\text { Parliamentary Elections) }\end{array}$ \\
\hline 1 & Reform of 1832 & $\begin{array}{l}\text { Whigs (with the support of } \\
\text { some of the Tories, facing rigi } \\
\text { opposition from most of the } \\
\text { House of Lords and the King) }\end{array}$ & $\begin{array}{l}\text { Whigs won in the very first elections } \\
\text { following the reform ( } 483 \text { seats out of } 658 \text { ) }\end{array}$ \\
\hline & $\begin{array}{l}\text { Reform in } \\
\text { Legislation } \\
\text { Concerning the } \\
\text { Poor, 1833-183 }\end{array}$ & Whigs & $\begin{array}{l}\text { Reduction in number of Whigs from } 485 \text { to } \\
385 \text { in } 1835 \text { elections. }\end{array}$ \\
\hline & $\begin{array}{l}\text { Factory law (ste } \\
\text { control of norm } \\
\text { of work } \\
\text { protection) } \\
\text { Annulment of } \\
\text { "Bread Laws" } \\
1846 .\end{array}$ & $\begin{array}{l}\text { Tory; Law annulling the Bread } \\
\text { Law (annulment of customs } \\
\text { bread levies protecting the } \\
\text { "homeland goods producer") } \\
\text { passed based on the initiative } \\
\text { some Whigs and voted for by } \\
\text { some of the Tory faction - } \\
\text { supporters of Prime Minister } \\
\text { Peel and the Whig faction }\end{array}$ & $\begin{array}{l}1847 \text { elections with a minimum majority - } \\
332 \text { seats out of } 656 \text { - Whigs are victorious }\end{array}$ \\
\hline & $\begin{array}{l}\text { Voting Reform } \\
1867\end{array}$ & Whigs & $\begin{array}{l}\text { Whigs increase their majority in } 1868 \text { from } \\
370 \text { to } 387 \text { (clearly not proportionately to } \\
\text { growth in number of voters) }\end{array}$ \\
\hline & $\begin{array}{l}\text { Voting Rights } \\
\text { Reform of } 1884 \\
1885\end{array}$ & $\begin{array}{l}\text { Liberal Party (Successors of th } \\
\text { Whigs) }\end{array}$ & $\begin{array}{l}\text { Liberals lose } 2.55 \% \text { and } 18 \text { seats (having lo } \\
\text { the absolute majority }-335 \text { seats out of } 670 \\
\text { as a result, after two unstable governments, } \\
\text { headed by conservatives in the first and } \\
\text { liberals in the second, suffered a devastatin } \\
\text { defeat in the } 1886 \text { elections: } 191 \text { seats out } \\
669 \text { ) }\end{array}$ \\
\hline
\end{tabular}




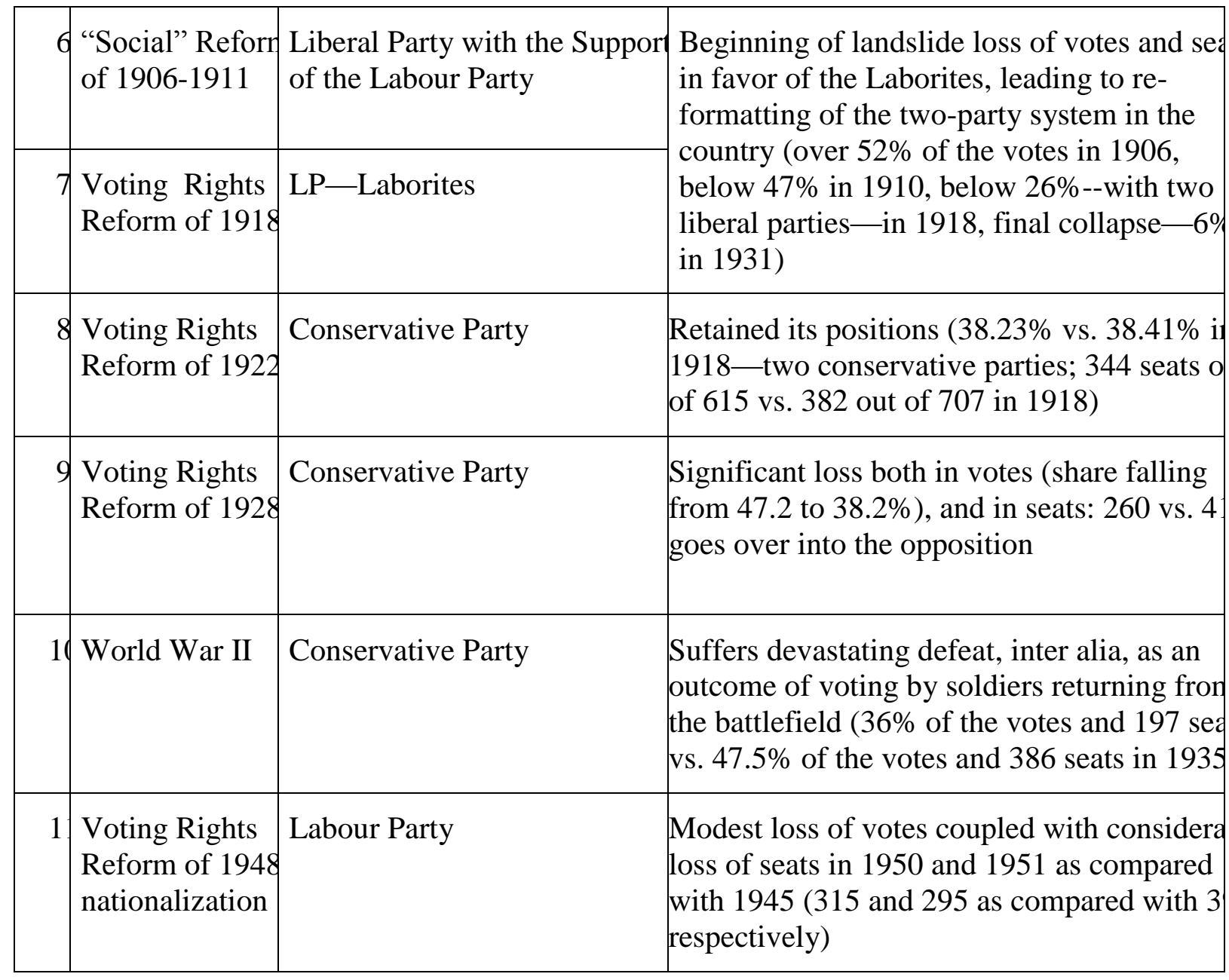

Source: Tanin-Lvov 2001, pp. 72-87.

Evidently, voters' motives can vary. The considerations impacting the choice ultimately made by voters are not at all necessarily bound up with the reforms which have already been introduced, however important these reforms may be. And even if there is a connection, the reforms, once having resolved the problem, could push it into the background. Even so, there is no avoiding the fact that it is well-nigh impossible to establish an influence of any significance which a voting reform as such may have on the following elections. This, perhaps, with the exception of the elections following the reform of 1928, in which for the first time millions of women took part who were not homeowners. The outcome was that the conservatives, after increasing the number of votes from 7.85 to 8.66 million, lost both in the share of votes and in seats, thus losing to the Laborites. Then again, in 1918, women homeowners, having first been granted the right to vote by the Liberal-Laborite coalition, also failed to evidence any statistically discernible gratitude. 
It is reasonable to suppose that England's political leaders were as a rule well informed, harsh people who were also far from being naive. If so, then the hypothesis that voting reforms were introduced based on expectations of new votes to be cast by voters for the first time "made happy" by having suffrage extended to them, appears to be inadequately grounded.

\section{An Electorate Subject to Manipulation and the Interests of Bureaucracy}

Taxpayer voters, ${ }^{17}$ like consumers, have a series of unique qualities. They are not interested in budgetary spending and have a high demand for control of spending resources, as well as for budget transparency; they have a negative attitude toward budgetary deficit, state debt, and these developments' fellow traveler - chronic inflation (Ill. 13.1 and 13.2; data for the period during the $19^{\text {th }}$-early $20^{\text {th }}$ centuries along with the following period, especially beginning in the 1960s, from the time of the complete formal elimination of a connection between payment of taxes and voting). They have no sentimental weak spots which may be taken advantage of to cover up for their failures,

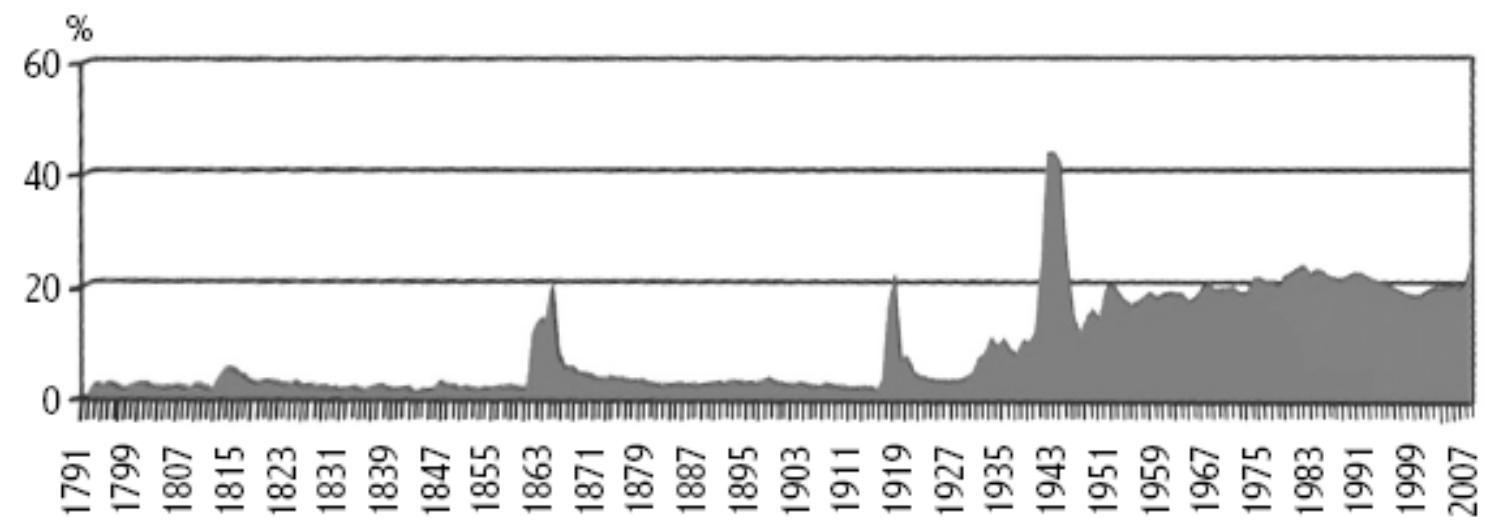

Sources: Calculated based on Mitchell 2007 and historical tables for the US budget project (beginning in 1930).

III. 13.1. Expenditures in US federal budget as shares of the GNP (beginning in 1930, shares of the GDP), \%

\footnotetext{
${ }^{17}$ Strictly speaking, this category may also include other citizens who make a sizable contribution to the "joint project" of providing pure public goods, for instance, by performing military service and the like, insofar as the fact that the notion of the "natural" functions of the state and of that every political decision "has a price," is harbored by all citizens personally paying this "price."
} 


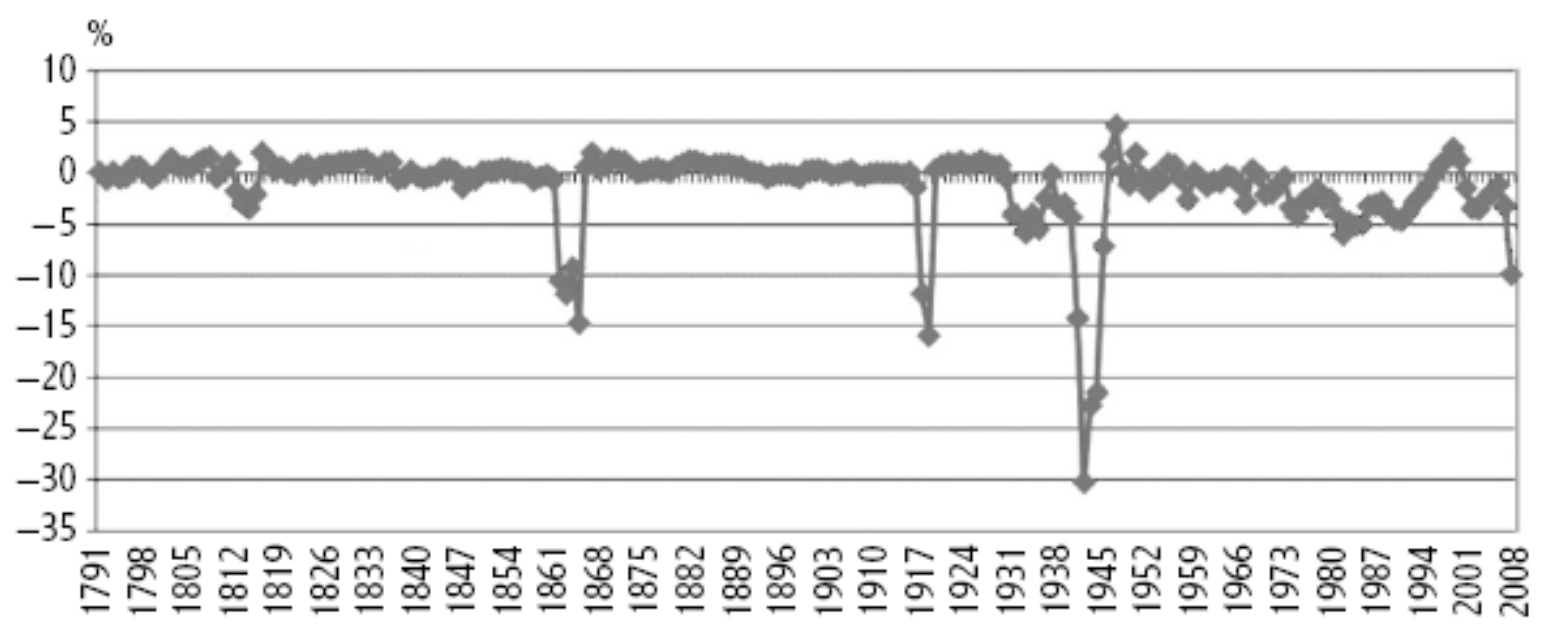

Sources: Calculated based on Mitchell 2007 and historical tables for the US budget project (beginning in 1930).

III. 13.2. Balance (proficit - positive, deficit - negative values) of the US federal budget as shares of the GNP (beginning in 1930 - share in GDP), \%

and inefficiency (in L. Erhard's phrase, they "patriotically buy from the one who sells the cheapest"). Finally, albeit they are easily predictable, they are not easily manipulated.

Taxpaying voters prefer a compact and inexpensive state which can protect them from threats to security and from chaos, a caring state with a constantly growing list of spheres of responsibility, competence, budget, and authorization. These qualities make it possible to mark the groups of players forming the "natural enemy"; that is, those whose gain has to do with extension of state rights and authority and with increased spending. These include a considerable number of officials, politicians, and intellectuals (for a more detailed consideration of some of whom see Chapter 2); i.e., those who are convinced of their right and ability effectively ("justly") coercively and in a centralized fashion to redistribute as great as possible a share of the GDP "in the interest of the public." The same coalition includes entrepreneurs who count more on advantages in having access to budgetary funds or on being defended from competition by means of regulations barriers which will, nonetheless, maintain a latch open for them as an exception - than on success with consumers.

For brevity's sake, this coalition and its numerous dependent "clients" may be labeled as "Progressive" (based, in part, on their own way of referring to themselves).

As rational players, members of the "Progressive" coalition aim to minimize losses. In the present case, minimizing losses is defined as maximum limitation of influence by the taxpaying voters. The most effective instrument for achieving this goal is extending 
the number of voters far beyond the limits of the body of the taxpaying population. ${ }^{18}$ This is why "Progressive" players rationally use means of Rule of Law democracy to turn the democracy of the taxpayer into a universal suffrage state.

In a state with universal suffrage, minimizing the influence of the taxpayers leads to decreasing expenditures and risks for the "Progressive" coalition. And indeed, advancing and grounding the need for continually newer types of regulations and spending is quite real in case if the costs foisted upon every voter are lower than the costs of selforganizing for the purpose of fighting against one or the other newly imposed tax burden (this was written about by Olson (Olson 1971) in models of special interest groups). And if, in Olson's model (just as in life), the majority is as a rule unable to defend itself from the parasitism of special interest groups, then the minority (the taxpayers in modern democracies) has even less of a chance to do this.

Things go especially well for proponents of peculiar interests when most of the public can "help," "defend" the real or the imaginary needy not out of their own pocket and not at the expense of their own free time and nerves.

With the store of homeland clients in need of care depleted (even if such a thing were in principle possible and even if such a thing did not in reality increase the number of those in need of aid at the expense of the number of those capable of delivering it), it is easy to come upon an endless supply of objects of aid beyond the borders of the industrialized countries. At the same time, the more aggressive the claims for aid put up by those receiving the care in a backward country, the more obvious their seeing it as their natural right or as a tribute which is owed to them, and the more desired they are as partners of the coalition in question (see Chapters 3, 6, and 10).

Successful use of pseudo-rights defense demagoguery for grounding "the right to immigration" of foreigners from countries with institutions which block economic growth, necessarily leads to a blurring distortion of the institutions in the "welcoming" countries. Thus, for instance, the proliferation of hearths of ideologies and terrorist organizations inimical to the very idea of individual rights, on one's own territory inevitably brings in its wake the need to grant the police and the special service taskforces unprecedented authorization for the purpose of protecting the lives of their co-citizens. This

\footnotetext{
${ }^{18}$ Evidently, with reference to contemporary reality, one should speak of the "net taxpayer," the one getting out of the budget less than he or she puts into it.
} 
while "non-politically correct" immigration legislation (discussed by us in the chapter dealing with these topics) could have prevented the very emergence of the question of such new authorization (Phillips 2009).

It is no accident that Fox TV channel in the US is reputed to be extremely conservative from the point of view of the "progressive public," despite the fact that conservatives and liberals are nearly equally represented in its programming. This state of affairs is due to that the channel's local news reports outweigh the international, thus considerably weakening the "progressive" group's ability of influencing the audience and demonstrating the must of providing aid for patronized overseas partners.

Unlike taxpayers and military workers, clients of groups included in the coalition are hard to predict, and incline easily in favor of supporting whomever may look strongest at the moment (Noelle-Neumann 1996; De Soto 2008). But they are easy to manipulate, manage, and bribe. For the members of the interest groups themselves, the budget deficit provides not a problem, but rather an additional opportunity for making discretionary (arbitrary) decisions concerning the distribution of means. Inflation as a tax not voted in by Parliament is a source of independence from voters. If it does not tear out of control, these groups' attitude to it is thoroughly positive. State tax, like inflation, becomes a problem only in case of uncontrollable growth at rates stably exceeding the growth of the economy as a whole.

To sum up: it is easy to see that the groups listed above (for a more detailed analysis of these groups, as well as those opposing them, see Chapter 2) have not only an interest, but also the resources sufficient for effectively advancing their spending initiative. Clearly, the mere fact of their having strong motives and the resources for performing some action does not automatically mean responsibility for the action performed. Yet the hypothesis cannot be discarded but calls for further development in the future that it is precisely these groups and coalitions that stand behind advancing voting rights reforms in the direction of universal suffrage, and reforms in state service systems - in the direction of a strong and self-sufficient structure independent of the elected politicians as well as of voters.

\section{Middle Class and Entrepreneurs in Favor of Universal Suffrage?}


Of essence is the question: what prompted the middle class to share their voting rights and increase the burden of the state?

Evidently, for people of middle or higher income level, no short and simple set of interests can be compiled. The interests of millions of agents and households cannot be identical, especially if long enough periods of time are taken into consideration.

It is, of course, logical to suppose that people not restricted in the financial means they have at their disposal in the period preceding the creation of the universal welfare state, normally achieved their wellbeing by hard work or entrepreneurship. They were also partly indebted to luck (including the part contributed by inheritance).

It is, accordingly, reasonable to assume that such people should be interested in both low taxes and reliable guarantees for property ownership.

At the same time, it is evident that situations arise in which, given certain conditions, these interests may be outweighed by others - short-term ones bound up with external shocks and quite independent of bureaucrats' interests, as we discussed this above. Such conditions may be:

Political circumstance; struggle with opponents and the attempt "to give the last squeeze" in a situation approaching a balance raise the demand for allies. Such allies may turn out to be precisely those groups whose contribution to the budget is minimal, but which may easily and quickly be bribed.

Interest in redistributing in one's favor the property of the more wealthy property owners by means of taxes (the case of Washington returning upon retirement to Virginia only to discover his landed property to be "dried up" - DeSoto 2004), or not to allow competition to become more intense by means of weakening guarantees for the less wealthy or by regulating business (Stigler 1970, mentioned above, on regulation promoting the interests of the middle class; a similar explanation of the support given by the "old" middle class to the "great mercantile state" in Latin America is provided by De Soto 2008);

Risk of losing in a competitive fight; hence the interest of any not overly lucky entrepreneur in weakening the one who has proven strong, talented, lucky (examples of the previous case: struggle of small producers of oil products against Rockefeller, of small railroad transporters in the US against the large ones who owned railroad networks, of weak farmers against the strong, and so on); 
Temptation for the entrepreneur and the inventor to provide the country with the fruit of his or her genius at the expense of budget guarantees (this is much more convenient and reliable than conducting one's own business at one's own cost and risk; the example of Wickers and his cannon, Cobden, $1864^{19}$ );

Temptation of support through state control, whose appeal is motivated by avoiding risk if we suppose that choosing the least risky strategies can seem best both to the principal property owner no longer getting involved in business and to the agent manager; then deriving a profit from discounts or special privileges offered by the state in the short term (which is the most important for the manager and easily observable by the property owner) may outweigh the almost inevitable large losses caused by regulation and profit not taken advantage of in the long term;

Wish of entrepreneur (or simply any economically balanced individual) to be free of responsibility and moral "fetters" by relegating the care for those unable to help themselves to the state (Deepak Lal 2007 cites the description of this state of affairs in Magnet 1993, p. 198); a wish thoroughly understandable in light of its bearer's public status - a status which leads to complications and humiliation for the wealthy and the successful, instead of acknowledgment and gratitude;

"Kindness" at another's expense, and occasionally even the wish to enjoy the same discounts along with the needy. As a result, the middle class often found that it, and not the poor, had become the winner after a redistribution policy would go into effect; moreover, at times the poor would be the ones to have to pay for the redistribution. Lal (2007) cites contemporary studies by the OECD on the "capturing of discounts" by the middle class; this particular but important case of redistribution is, naturally, treated by Stigler (Stigler 1970).

The reasons enumerated above prompted and continue to prompt taxpayers and people quite sound economically who suffer from excess tax and regulation loads, as well as from paupers' and interest groups' racketeering, to join the coalitions formed by such "bandits" rather than the coalitions which oppose them.

A significant reason for the success of pro-redistribution coalitions in the business of distorting the foundations of taxpayers' democracy may have been the weakening of the

\footnotetext{
${ }^{19}$ See the speech "On State Production Plants and Workshops," made by R. Cobden in the English Parliament, on July $22, \quad 1864 . \quad$ EconLib, $\quad$ Volume I FINANCE. Speech VII. House of Commons , July 22, 1864 http://www.econlib.org/library/YPDBooks/Cobden/cbdSPP33.html \#Vol. I, Finance, Speech 7
} 
barrier which had existed on the level of basal institutions: the family, morality, and religion.

Historically it became the case that in Europe, the establishment of ideas of freedom (both economic and political) and institutions supporting it, proceeded as part of a struggle against religious institutions (De Tocqueville 2000 ${ }^{20}$ ). Formal European church leaders most often rejected (and continue to reject today) the ideas of freedom. This is partly explained by their claim to a special relationship with the state, a relationship rooted in a centuries" old tradition of "whosever authority - his, too, the faith." In the US, where religion became an exclusively personal matter, while religious leaders typically shied away from politics, this conflict proved possible to avoid. The success of Europeans in their struggle against the religious imperative, which we have already mentioned above (see Chapter 11), inevitably distorted the foundations, that "soft infrastructure" supporting the institutions of freedom and the market.

A problem specific to the US became the conflict between North and South, leading to the American Civil War, catastrophic in magnitude by local standards. The war proved impossible to prevent by the tactic of compromise so universally accepted here. The war destroyed hundreds of thousands of the most motivated, highly "qualified civically" men (counting the high share of volunteer participants); it thus caused irreparable damage to the store of habits of the civil self-organization and quality of religious traditions. ${ }^{21}$

A problem common to all countries governed by Right of Law democracy has become the crisis of family and morality, a crisis unavoidable, given rapid urbanization. The cities take in a mass influx of young people finding themselves outside all familiar parameters and restraints of the rural community; such an influx could not help creating great tension for the "soft infrastructure" - morality and the family. The problem was temporary, but was marked by ever growing state intervention, which pushed out the natural institutions of inner family solidarity and mutual aid, replacing them with coercive state mutual aid on the national level.

The problems detailed above may all have left the foundations of the Rule of Law constitutional democracy of the taxpayer intact. Disparate impulses of this kind could

\footnotetext{
${ }^{20}$ A. de Tocqueville wrote:

Philosophers of the 18th century explained the weakening of religious beliefs very simply. Religious devotion, in their view, inevitably extinguishes as freedom and knowledge blossom. Vexingly enough, the facts do not confirm this theory... I knew that religiosity and love of liberty differ from each other among us. But here I saw their intimate connection: in this country, they rule together.

${ }^{21}$ In other words, the greater part of the human capital which had supported Rule of Law institutions had been destroyed. We considered this element of human capital in the Introduction in connection with the discussion of Shleifer and Acemoglu.
} 
have been extinguished, while interest groups' activism could have been limited provided there was a high barrier to take in decision making concerning budget extensions and voting rights for state budget employees. In order to erect such a barrier, it was clearly not sufficient simply to cast a constitutionally limited democracy of the taxpayer as a particular value opposed to the anti-good embodied by the authority of the mob (Aristotle 1997; Adams 1788).

Such a barrier could have been a formal constitutional prohibition - a prohibition complementing informal notions and consensus obtaining in society similar to the way that widespread values and rules concurred in by society in the US were fortified and fenced in by appropriate prohibitions as specified by the Bill of Rights. Such prohibitions could have become:

Prohibition for the state to act beyond the limits of a strictly defined sphere of responsibility (providing pure public goods);

Universal (and not only for the residents of the Federal District of Columbia) prohibition against extending the body of voters at the expense of the budget's clients.

\section{Once Again Concerning the Model of "Resource Curse": Universal Suffrage and Annuity Revenue as an Instrument for Corrupting the Voter}

Let us turn to the model of "resource curse" introduced in Chapter 6. There we made the allowance that in a state with population $\mathrm{N}$, the citizens maximize their own utility, which is a positive function of the consumption of public goods $X$ and the possibility of having an impact on the policies of state $\mathrm{V}$ and a negative function of payment of taxes $\mathrm{T}$ ( $\mathrm{X}$ and $\mathrm{V}$ are thus in part mutually exchangeable goods).

The state's profit at every moment is considered identical to the profit of the agents employed in power agencies and state management.

The state holds a monopoly on providing public goods.

Public goods (X) are created using money obtained through taxes (T) and annuity rental payments $(\mathrm{R})$. There are no other sources of income, there is no budget deficit or pro-ficit, and so $\mathrm{X}=\mathrm{T}+\mathrm{R}$. 
The state is founded upon democratic institutions; that is, authority is realized through the involvement of the people, and is bound up with the need to return to the people part of the influence $\beta(0 \geq \beta \geq 1)$. At the same time, value $\beta$ in the model was interpreted as an index of democracy.

The state will aim as much as possible to reduce $\beta$, that is, to concentrate authority in its own hands, considering that its utility function is also positively dependent on authority (V) and grows as authority in the hands of the citizens diminishes (i.e., as $\beta$ goes down).

As part of the model, rationally motivated citizens had to decide whether to accept the artificial limitation bound up with the non-increase (the decrease) in democracy level of the regime in exchange for receiving a share of the annuity rental payments from the state, or to preserve their prerogatives as voters. And if a considerable enough part of the annuity rental payments goes toward making a deal come true between the state and its citizens, then annuity payment income for the state will lead to lowering the level of control of the state by the citizens (the level of democracy).

But a similar situation - exchanging the right to vote (as an instrument of de facto control over the authorities) for payment - can arise without there being a petroleum fountain in evidence, too.

Let us assume the existence of two voters' groups. One, the "wealthy," are the net payers of taxes, for whom income from state redistribution along with mixed public goods amount to much less than the taxes which they pay. For them, the situation is clearly similar to the model described prior to the appearance of high annuity rental payments.

The other group, the "poor," are the net recipients of mixed public goods and handovers from the "wealthy." Once it becomes obvious that, for them, it makes no difference whether the goods they receive originate in petroleum income or taxes levied from the "wealthy," the situation turns out to be identical to the one in the model described above, after the high rental annuity payments make their appearance. Freedom (as the antithesis of manageability) clearly constitutes much less of a value for this group than it does for the first group; the same is true for the majority of voters in the model where the high rental annuity payments have already made their appearance.

Moreover, in this case, the state turns out to be interested in purchasing (attracting) voters from beyond the limits of the traditional circle of citizen taxpayers. Such new 
citizens may be those de-socialized elements who had no voting rights earlier; immigrants, including even those who are a priori holders of inimical attitudes toward the country granting them asylum. The "vote for share in the rental annuity payment" deal is profitable both for the official and for the immigrant of this kind.

It is also of no small significance in this case, at what stage of state institutions' formation the opportunity for such exchanges (i.e., universal suffrage) presents itself.

In an old Rule of Law democracy with a strong tradition of authority, law, and reciprocal link between the right to vote and payment of taxes, the magnitude of the problem will for a long time remain limited. This is the case as a result both of the resistance by the traditional body of voters and thanks to the independence of the legal system which to some extent limits even the almightiness of the voter (or of whomever manipulates the voter).

But, as time passes, the likelihood grows that the regime of the rule of the law will become distorted; in this case, the court of law system as a non-elected agency may become a substantial hampering obstacle on the way to emerging from the crisis (see Chapter 9). If that proves true, leaping over the barrier will require extraordinary measures involving profound constitutional reform.

A young democracy, by contrast, is one in which voters have as yet no experience of operating legal institutions; it is also one in which the voters have as yet not become conscious of all the advantages of a political elite split by competition and regularly appealing to the voters as arbiters. The voters' evaluation of $\beta$ is in this case not very high. Such voters will, accordingly, much more readily part with this good than citizens of old and relatively effective democracies would.

\section{Rights and Privileges}

The law is a universal limitation of power; it constitutes a prohibition coupled with threat of imposition of penalty against performing certain actions which endanger the life, health, property, and dignity of private persons. The prohibition applies to both state agencies and leaders, as well as to private persons in their dealings vis-à-vis each other.

The law is rooted (is supported) by morals. An example can be taken from basic rights (see the definition given in the Introduction). 
Privilege consists in unpunished violation of a prohibition, authorized by unlimited authority (pardon, indulgence). As a rule, it is of a one-time, accidental, exceptional nature. For instance, tax exemptions, or access to persons making decisions (in medieval European tradition this found its formal expression in the privilege to take part in certain court ceremonies).

A privilege's regularity and tradition, along with its distribution among a certain class of relationships and population group - all this opens the way to the privilege's developing into a right. A group enjoying a privilege gradually begins to think of the privilege as its "due," even if formally the nature of the relationship with the authorities is confirmed by "ratification of age-old rights" (privileges, in essence) at the time of each new monarch's ascension to the throne.

Transition from privilege to right. Privileges redeemed from kings (the state), given power polarity and possibility for the privileged group to defend its privileges by force, as well as buttressed by tradition of long standing, begin to be seen as a right. Universality may be supported by religious morals, as well as by legal form extending the number of persons interested in defending the privilege which had been introduced by others and extended to a more general population spectrum (the Magna Charta ${ }^{22}$; the gradual elimination of rights denial for religious minorities in Europe in the $17-18^{\text {th }}$ centuries; land reform in France after the French Revolution in favor of a pollinated and politically passive peasant majority, and so on). New beneficiaries, armed and interested in defending their privileges, become the basis for extending the coalition for the defense of the new order against attack.

Such a mechanism of rights gestation based on privileges, by contrast with what is described in North, Wallace, and Weingast (2011), provides a simple explanation for the interest taken by representatives of elites which feel their rights to be trespassed upon, in extending the number of users enjoying the privilege to the point of converting it into a right.

Transition from right to privilege. Mastery of right does not at all mean that privilege demand drops to zero. In the discipline of economics, special interest groups and their activism have become an almost classic example of the struggle for privileges of all kinds (Olson 1984).

\footnotetext{
${ }^{22}$ The Magna Charta of Liberties, signed on June 15, 1215, which became one of the principal constitutional acts of England.
} 
One of the outcomes of the struggle for privileges for such groups includes the so called second-generation rights (collective, pertaining to groups arbitrarily designated). In this case, coalition extent and the hope entertained by elected politicians of enlarging their electorate and of obtaining a new support basis, led to the extension of suffrage in England after the reform of 1832. The reform practically made suffrage (as the right of the taxpayer to be represented in Parliament so as to dispose of the monies paid as taxes) general, in the sense that anyone could become a voter based on perfectly formal and achievable indications.

\section{(Two paragraphs omitted - see full version ${ }^{23}$ )}

\section{Degeneration of Democratic Institutions (Court and Press)}

The elite engaged in redistributing means of the "caring state" are interested in undermining the foundations of a Rule of Law democracy: independent court, mass media competition, and politics; more and more rights and authorizations are transferred from elected agencies to non-elected ones.

As has already been noted, the last one hundred years have seen growth in tendencies thoroughly dangerous not only for the basic rights of the individual person, but also for democracy as such.

We should here make use of a phrase of Przevorski's (Przevorski, Alvarez, Cheibub et al. 2000, pp. 15-18), who notes effective political competition as a key indication of democracy: "Under democracy, the authorities may well lose in the elections, and, having lost, calmly join the opposition."

As comparative analysis shows (Mau, Yanovskiy, Javoronkov, et al. 2007), in order for there to obtain an effective mechanism of real change of authority, it is not enough for the citizens to alter the parliamentary majority and the government. Also a must are, at least, courts of law independent of any government (and not only independent of the "wrong" kind of rightist government), as well as independent, acutely vying with each other means of mass information (the mass media).

New universal welfare state "values" lead to ever more noticeable degeneration of these key institutions of Rule of Law democracy.

\footnotetext{
${ }^{23}$ See http://instecontransit.org/ "How the Import of Modern Western Institutions Suppresses Economic Growth: 1990-ties East-West and West-East Transition" or the book structure and the chapters' content short description.
} 
Using state care for providing the citizens with "quality and impartial" information and additional services in the area of culture and education, state ("public") media empires have emerged, funded at the expense of the citizens. There is hardly any serious discussion of the possibility of impartial broadcasting, given conditions of evident conflict of interests. Workers of such companies are interested in the extension of budgetary expenses in some way pertaining to key items on the political agenda during any elections; thus, they naturally tend to favor the appropriate political forces (see Chapter 2 for further details). Journalists and editors working in these companies are not limited by demand, market, interests of audience or advertising agency; all these are compulsorily paid for by the taxpayers. Just as in the case of bureaucrats, so these people's interest also consists in obtaining the largest possible share of the budget while remaining protected from control of any kind. (For instance, control may leave them without income from secret, undeclared advertising, such as interviews or invitations to participate as discussion partners chosen based on criteria which do not coincide with the interests of the audience.)

Private broadcasters are unable to compete in a key area (key from the point of view of the must of defending democracy): in reporting political processes and news, even if the broadcasting is not interrupted by force. The truth of the matter is that the majority of the population is little politicized, a fact which means that advertising can cover the costs of political broadcasting only during periods of heightened interest in politics. Now if, besides, there already is a competitor on the market, one all of whose political broadcasting and news expenses are paid by the taxpayers, then there is, for all intents and purposes, no way to outplay such a competitor in this sphere. This is why commercial channels as a rule offer frivolous shows, films, and music, all loaded with advertisements. Such, precisely, is the media market in most Western countries (with the exception of the US and Italy).

Non-elected agencies cast themselves as defenders of minority rights (the sum total of the minorities long since comprising the majority): women, immigrants, the handicapped, the poor, and others. This is why they accept the "duty" of compensating for the inability of all the groups mentioned above to defend their own interests in court and during elections. The same is also done by means of interpreting the law in favor of the "poor," the interpretation being unlimited by either law or common sense. Such a condition is typically labeled as "supremacy of the law," while criticism of it (see Chapter 1) is equated with undermining the foundations of Rule of Law democracy. 
If the state does not defend the authority of the law, but on its own makes decisions for the citizens about their needs, then court judges develop the desire not to connect the interpretation of the law with values accepted in society, but to "reeducate the populace." This was the view put forth unabashedly by A. Barak, Chairman of the Supreme Court of Israel.

In countries such as Israel and Italy, thanks to a peculiar system of appointments (self-appointments, in essence ${ }^{24}$ ), judges have been able to get rid of any form of control over politicians elected by the people. ${ }^{25}$ A similar system was also being constructed in Russia in the 1990s, when agencies of the judges' community often "squeezed" the best judges out of their ranks. At the same time, however, an unprecedentedly high level of independence of the court system as a whole was provided in our country.

In Israel, judges at the summit of the judicial pyramid are absolutely independent, while other judges lack the most elementary independence. Judges of regional and justice courts may be dismissed from their offices by senior colleagues at minimal expense. A criminal investigation against a judge begins based on the decision of the Attorney General and the regional appeals court. The Supreme Court Chairman can at his discretion remove an accused judge from his or her post for a period of time the Chairman himself designates (Article 12 of the Law Concerning the Court System). The Supreme Court Chairman appoints the members of the disciplinary court to investigate appropriate accusations against a judge, with this team also being empowered to discontinue a judge's authorization (Article 13 and Part 5, Article 7 of the same Law). Finally, the Supreme Court Chairman prepares materials for the decision to be made by the commission for election of judges concerning the discontinuation of a judge's authorization (Part 4, Article 7).

In practice, a conversation with the Supreme Court Chairman is usually sufficient for a judge to be suspended. Following such an exchange, the judge himself writes a resignation request. This means that in Israel, in order for a judge to be deprived of professional status and authorization, the Chairman of the Supreme Court needs only to reach agreement concerning the matter with the Attorney General.

\footnotetext{
${ }^{24}$ For further detail, see: http://www.azure.org.il/magazine/magazine.asp?id=174\&search text=elections, «The Court That Packed Itself.»

${ }^{25}$ In all other democratic countries, participation in appointing the legislative (in order to provide publicity) and the executive authorities takes on a combination of different forms. In all countries abiding by the right of precedent, removing a judge from his duties takes place by following an intricate system of impeachment by the parliamentary majority qualified to carry this out. The requirement guarantees the judge up until the time of retirement the same level of protection as is afforded for the President of the US.
} 
Thus the "system," or the corporation as a whole, proves independent, while independent judges in it are practically impossible to find.

The processes described above gradually turn the ruling authority from a democratic into an increasingly oligarchic one. The courts and the press - two non-elected branches of power - are no longer each other's counterweights, but form a union based on common interest - defending both oligarchical structures from competition and control by the voters. The union of the press and the legal system, which took shape historically, for instance, in Israel, has a number of times demonstrated its ability to turn the position of any elected politician by 180 degrees (B. Netanyahu, 1996-1999; A. Sharon, 20032005; see Yanovskiy, Zatkovetsky, et al. 2007). Italy's special feature, with its equally politicized court system and self-appointments, consists in domination of the media market by rigid competition. This has been the reason why it has proven impossible to push a perennial leader of the Conservatives, who is also at the same time the owner of two large TV channels, out of politics. Failure to dislodge him comes despite regular attempts to exert pressure by means of the legal system.

In the US, where, it would appear, the most authoritative and stable court system is maintained, symptoms of similar "institutional malaise" are in evidence. Future judges' non-elected mentors, having despaired of usurping the court system, preach transferring its authority to the politicized "international" court agencies. This should lead to thoroughly predictable consequences, for instance, for the US Armed Forces, should a number of first officers need to appear before the tribunal in the Hague.

The advancing process of strengthening of the non-elected authority undermines the authority of the voters. At the same time, motivation to serve voters' interests grows consistently weaker not only among judges and journalists, but also among elected politicians.

\section{Secularization and Its Consequences}

Supremacy of the law (legal authority) for a time provided a safeguard for life, liberty, and property as natural and inalienable human rights from attempts mad upon them not only by other people, but also by the state itself.

Above we have already discussed the problem of the destructive impact of the $19^{\text {th }}$ century liberals' struggle against the Church. While this struggle was in process, the "soft infrastructure" (Niskanen 1998) bound up with the idea of eternal, universal imperatives given from on High or formulated as a result of evolutionary selection, began to blur. 
This inevitably struck at the essentials of constitutionalism. Accordingly, the blurring of the authority of the idea of law and Rule of Law state, which was to be observed at the same time, should also come as no surprise to anyone. Thus, the absence of one single morality binding upon everyone leads to the idea of absence of one single law binding upon all, a law as per which all have equal rights and obligations.

Once the authority of the law rooted in morality given from on High, was replaced by the product of the activity of persons with changing interests and unstable reputations, society is set to go further. The idea of justice as equal treatment of both rich and poor begins to be pushed out by the diametrically opposed notion of the must of repartition of the property of the rich by the "enlightened leaders" in "favor of the poor," a repartition which would be "just" and as if a compromise (between the interests of the poor and the rich). ${ }^{26}$

In point of fact, however, this very motion distorts the foundation of modern civilization, which consists in individual rights. These rights are pushed aside by the "rights of the collective," or the group (formerly "downtrodden and discriminated against," naturally), a turn of phrase which in practice means an official's arbitrary will.

Given a flexible morality and such a notion of justice, flexible law will triumph. Given a flexible law, a corresponding kind of law court emerges. The former court system in old Rule of Law democracies (the Anglo-Saxon ones, in particular) is crowned not by its own corporate elite, nor is it subordinate to this elite, but rather to the supreme court. A court in which each judge is independent, subordinate not to the head judge (Chief Justice), but to that selfsame supreme law, simply cannot "oscillate along with the party line."

A new court can be both extremely servile and outwardly thoroughly independent. The crux of the matter is that it must defend the new morality-propagating elite and be maximally flexible. Particular success on this route has been met with in Italy and in Israel (see below); their example finds many interested emulators.

\section{Officials' New Priorities}

\footnotetext{
${ }^{26}$ In reality, frequently enough, this is, naturally, not in favor of the poor, but in favor of the “enlightened" (Stigler, Spring 1971, pp. 1-21).
} 
The leftist ideology dominant for a series of reasons (see Chapter 2 for further detail on the leftward shift in the system of education, and Chapter 10 on the "closed democracies") propagates the myth of the severe burden of military expenses which does not make it possible to help the poor or to solve social problems.

The diagram in Ill. 13.3 reflects the real costs of "guns ${ }^{27}$."

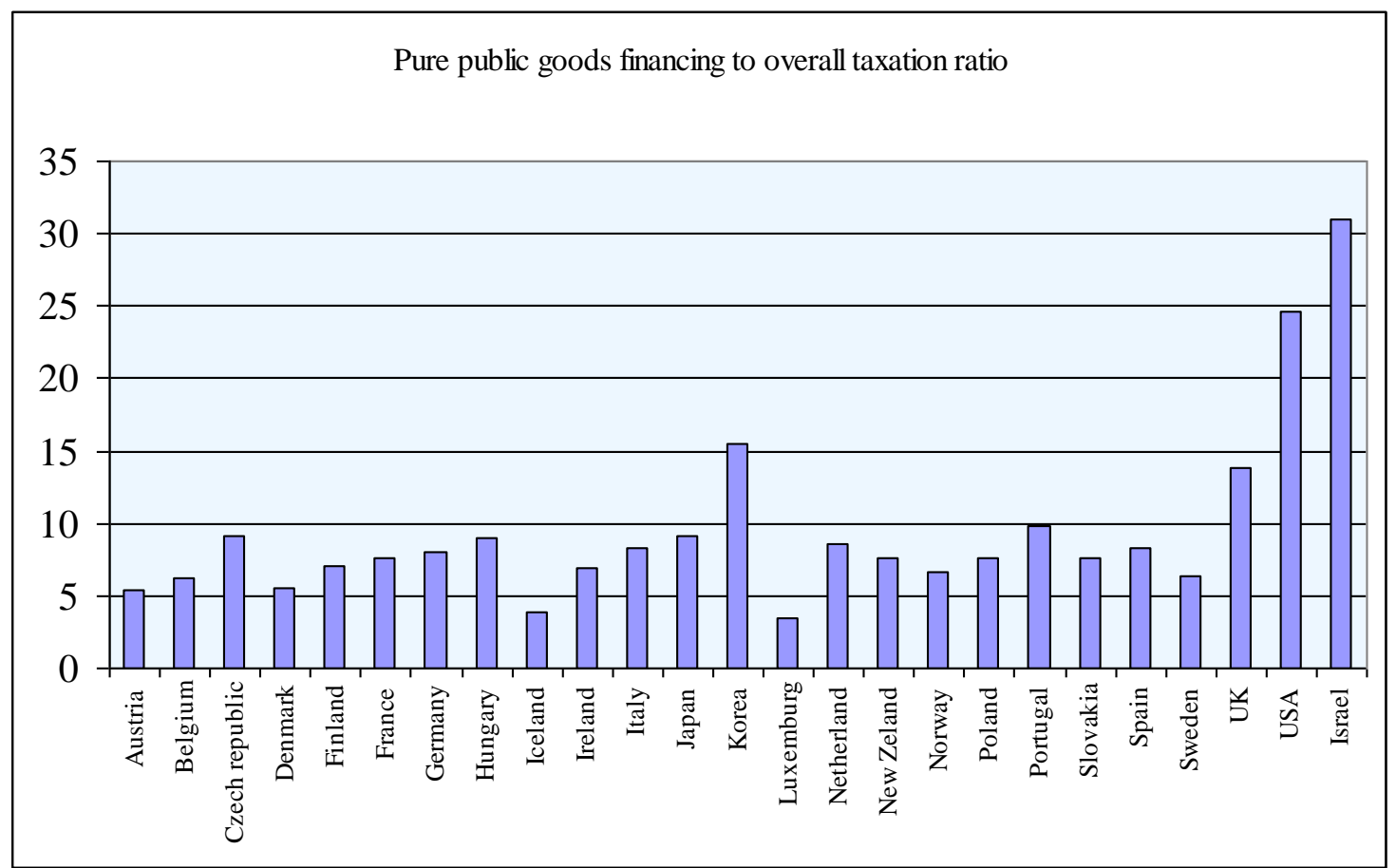

Sources: OECD in Figures 2007; Bank of Israel (http://www.bankisrael.gov.il/deptdata/mehkar/indic/eng_f01.htm).

III. 13.3. Pure Public Goods Costs in Relation to Taxes, 2004, \%.

The bar graph makes it clear that only in four developed countries (Israel, US, Great Britain, and Korea), more than $10 \%$ of the resources amassed through taxation are spent on performing the principal duties of the state in defending the citizens and providing law and order. Even in Israel, where this indicator is the highest, the sum totals for defense, security, and justice lag behind both spending on social and redistribution programs and spending on servicing state debt; i.e., they are third in significance.

The client voters, attracted by redistribution programs and programs for providing "mixed public goods" and "social aid," by voting accordingly, redistribute resources in favor of state employees - the bureaucrats. Voters, who are also the net donors of the

\footnotetext{
${ }^{27}$ For more details and for statistical analysis see "How Safe Is It, to Confuse Defense with Care?" working paper http://papers.ssrn.com/sol3/papers.cfm?abstract id=2236354
} 
budget, are left without guarantees of their principal rights, while also bearing a growing tax burden.

A significant part of the electorate, who are also the beneficiaries of social programs, tends to sympathize with demands along the lines of "butter rather than guns". But it is clear that they can obtain their special benefits only in a mediated fashion, while what is confiscated from the wealthy is transferred to be put at the disposal of state employees. As spending on "social needs" grows, more and more bureaucrats show up who work in some kind of "ministry of social love and care." These bureaucrats" objective interest is to achieve a maximum concentration of resources subject to their control (Niskanen 1971).

It bears emphasizing that the level of military spending as a rule does not go down (as the share of the GDP); it simply does not grow. Then again, in Israel, the GDP share of these costs dropped as compared with the late 1980s. However, insofar as the economy at the time was undergoing rapid growth, no absolute reduction of costs took place in this country, either. As we have already noted, the chief criterion of effectiveness - decisive victory over the enemy in the battlefield - has disappeared. This means that it becomes easier and more profitable, when army spending is redistributed, to lobby for spending on costly "high tech" weapons than for weapons of the perfectly effective regular kind. Costly technology creates a stronger impression on the politician placing the order (who is normally also an ignoramus when it comes to technical appliances). 


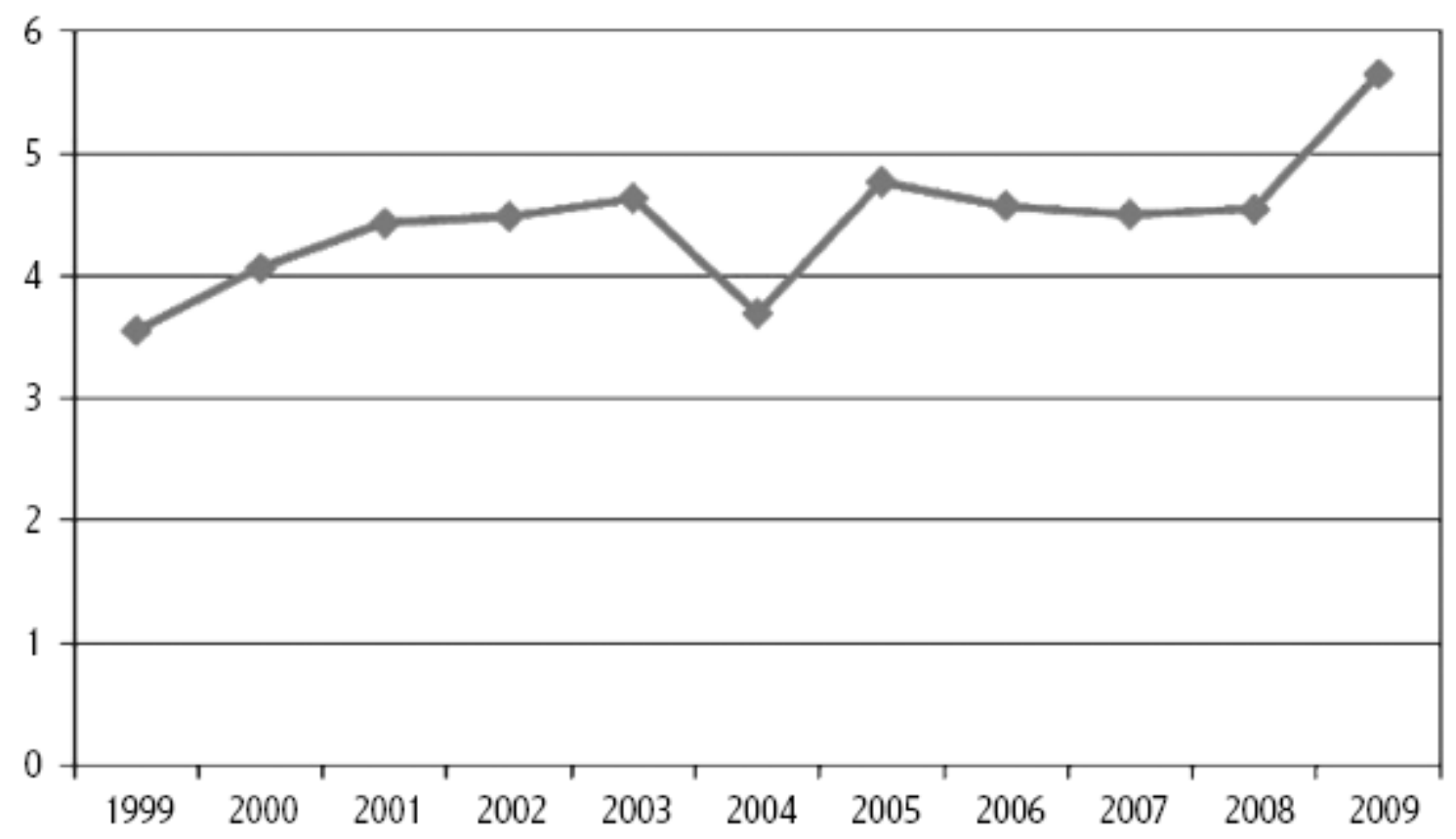

Source: Calculated based on the Rosstat (Russian Statistics, GDP) and State Treasury data.

III. 13.4. Russian Federation Sum Total Spending on Defense, Security, and Law-Enforcing Activity, \% of GDP

This makes the politician easier to convince about acquiring the tech appliances, even if the effectiveness of the "ultra-modern" and super-technical weapons provokes wellgrounded doubt. ${ }^{28}$

For purposes of comparison: in the Russian Federation (unconnected to spending quality) resources earmarked for defense, security, and law enforcement rose notably in 2000 as compared to the 1990s, when they made up less than 10\% of the total federal budget costs.

But even now they do not exceed $15 \%$ of the sum total of the expenses of the federal budget or $6 \%$ of the GDP (Ill. 13.4).

This growing laxity in control by the voters leaves the "parquet generals" in a peaceloving mood, managing to do this, perhaps, even more decisively than the new military legislation and justice can manage to do for the officers.

Against the backdrop of lowered moral norms and absence of due control by the courts and the press spoon-fed by the state, demoralization of state officials sets in. In a "mixed public goods" state (put simply, in the "welfare state"), officials are objectively interested in a wrapping up of the defense functions of the state and the elimination of the

\footnotetext{
${ }^{28}$ See, for instance, the incident with the laser beam: B. Sweetman, "Laser Weapons Gain Momentum," in Aviation Week, April 21, 2008.
} 
idea of state responsibility for security. All this makes them first tangential, and then immediate allies of those who threaten citizens' lives. The state puts forth the main task of its official not as "defending the citizens against the enemy," but as an "acute social must" of appropriating money for defense against "poverty." In order for this requirement to be met, it is more convenient to suppose that the life of one's fellow is a relative good which can well be sacrificed for the sake of "higher goals" (for instance, peace in the entire world, social progress, the triumph of multiculturalism and tolerance - add according to taste). There is no putting a halt to this process. After death for the Fatherland stopped counting as an act of valor, death of the enemy became a crime (as an instance of "excess" or "disproportionate" use of force), since the army turned de facto into an international police force protecting not its own citizens, but some "higher goals."

\section{Universal Suffrage State: Short List of Problems}

As a regular outcome of extending suffrage to net recipients during the last 100 years, the state has begun to care for everything and everyone, with the budget in the developed countries beginning to show considerable spending on "social needs" (for further detail, see Appendix II to the Third Volume). The spending grew to the point of considerably - in many instances, a few times-fold - exceeding the share of military spending, which evidenced almost no growth during the same period of time. Persons believing themselves to be enlightened ascribe to themselves the right forcibly to redistribute resources, supposedly "in the interests" of the majority. Representatives of this last are presumed to be limited in their capacity for concerted rational action (for further detail, see Chapter 3), and thus in need of protection. Well-to-do active citizens have weaker property guarantees, becoming dependent. ${ }^{29}$ The others are perverted by the hope of being granted what they have not earned, becoming even more dependent than they had formerly been.

\footnotetext{
${ }^{29}$ Some of the wealthy (dubbed "progressive" or "patriotic") themselves take an active part in the division of the property of others, thanks to a "correct" attitude which they harbor toward the authorities. These last provide the "correct" entrepreneurs with access to orders, protection against competition (often under the banner of "antimonopoly" struggle, i.e., not struggle against the state's "favorites" who receive monopoly privileges from the state, but struggle against the most successful and strongest companies which have the "monopoly" affixed to them. Indeed, who else has the greatest chance of obtaining the greatest share in the market: either the one who is strong due to an ability to please the consumer, or else the one rendered strong due to proximity to the ruler). Thus, a negative selection takes place in business. When instead of the consumers, the market, and competition, it is the state that takes charge of selection (via the agency of the police or the office in charge of "protecting" competition), the boundary is blurred between authority and property. But it is the precision of this boundary that is one of the principal conditions of a favorable business climate and long-term economic growth.
} 
Never in history have dependent agents been able to support or protect morality. Recipients of aid from the state are not interested in thorough and rigid control over the state become a large general source of social programs. In a society made up of aid recipients, there is objectively no demand for strong independent mass media in control of the state and capable of exposing both the authorities and the man gone to pot in the street.

There is a multitude of arguments pro and against state social policies which forcibly redistribute the property of the wealthy in favor of the poor. We single out three points which, in our view, are the most important in evaluating these policies.

These policies are amoral insofar as they contradict laws which protect private property (it is immaterial whether these laws hail from the will of the Creator or from laws of Nature).

Even if they were moral, history has proven them ineffective in achieving social goals. $^{30}$

Even if such policies were effective in achieving "social" goals as such, society which they pervert would typically become incapable of concerted action, and, thus, incapable of survival.

The cost of these policies involves chronic budget deficit, correspondingly growing state debt, and chronic inflation. That is, drastic worsening in quality of such a market institution as money provides a precedent for taxation not approved by the parliament. The claim that these problems are insignificant insofar as they are well under control, fails to take into account the element of trust put in the authorities. The loss of trust put in the government both in connection with steps taken by the "monetary" authorities and those bound up with other fiascoes of the government automatically leads to a drastic loss of governability. ${ }^{31}$

\section{Conflict of Interests of Elected Leaders with Interests of the Voters (Budget Recipients)}

\footnotetext{
${ }^{30}$ It is important to emphasize that totalitarian deviations (whether socialistic ones or the national-socialistic ones thoroughly close to them) from this itinerary did not simply fail economically by the end of the 1980s. Claims put forth by the proponents of socialism of all stripes to would be greater humanity, spirituality, and justice of their model, also need to be dismissed. The implementation of these models in the 20th century led to the barbarization long since forgotten by Europeans, including cannibalism, mass mutual reporting, and so on

${ }^{31}$ For further detail, see Appendix V.
} 
Conflict of interests is a well-rehearsed topic which, nonetheless, usually does not concern voters. Clearly, the person "in need" is a recipient of budgetary funds, votes for higher taxes and spending, and finds himself in a situation of conflict of interests. Officials and experts, journalists and other mass media workers who stand to benefit from high budgetary spending, if they obtain additional income opportunities, or even if they don't but, according to Niskanen's model, gain additional career opportunities and perspectives, also find themselves in this situation (something transparently corroborated by the electoral behavior of residents of the Federal District of Columbia; see Ill. 13.5).

Elected politicians run into a conflict of interests if they have the opportunity to use the resources entrusted to them not in order to provide public goods, but so as to prolong their term in office.

The very appearance of models of the politico-business cycle (Nordhaus 1975) is indicative of researchers' certainty that such an opportunity really exists and must be taken advantage of.

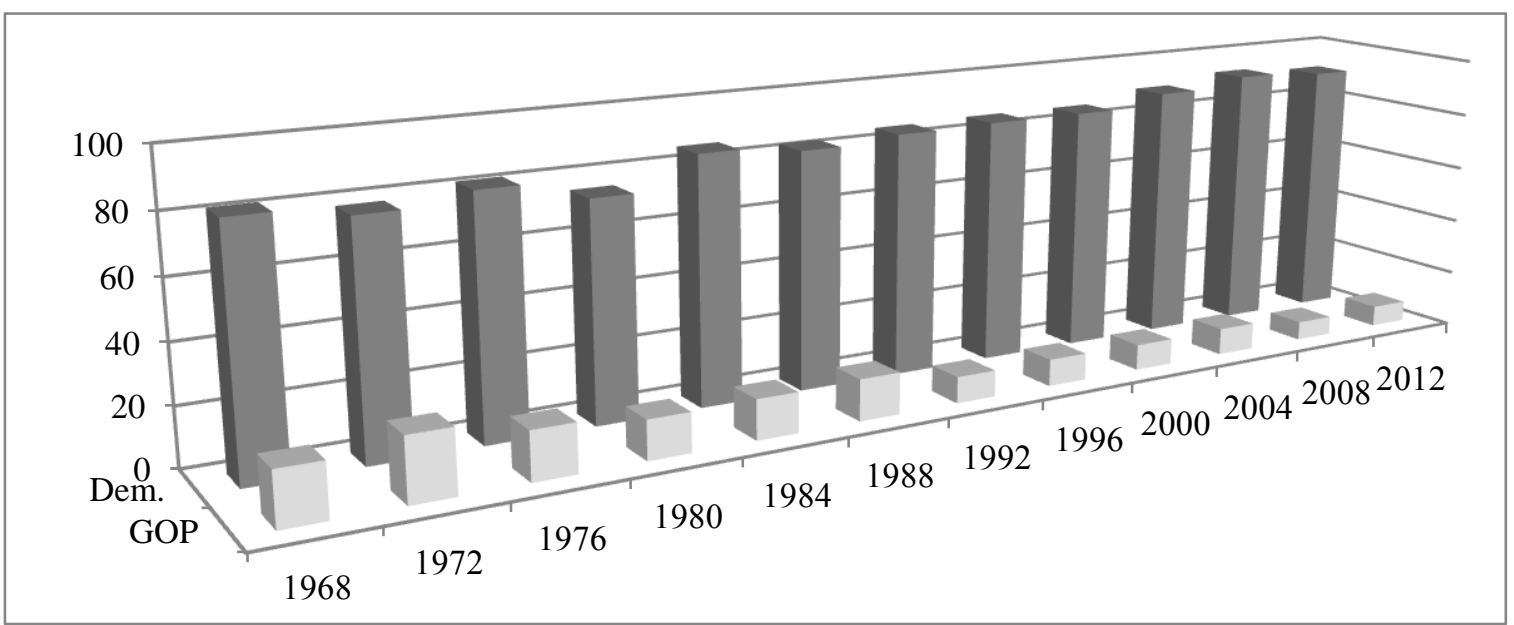

Source: Clerk's office at the US House of Representatives, http://clerk.house.gov/member_info/electionInfo/index.html.

III. 13.5. Voting in presidential elections in the Federal District of Columbia in 1968-2008: domination by the party of supporters of expanding social programs among formally de-politicized federal employees of the capital district.

\section{Moral Aspect of the Taxpayer's Democracy and Universal Suffrage}


Voting by the taxpaying electorate in favor of spending provided for by the voters' own contribution to the "common cause" (res publica) leads to no moral dilemmas. It is an entirely different matter when it comes to voting for confiscating from someone money or other resources for one's own benefit, or for the benefit of a third party (generosity at another's expense). All this concerns confiscation not in extraordinary (such as wartime) conditions for the purpose of urgently saving the lives of one's co-citizens, but during the most usual of peacetimes for the purpose of "greater equality," without any qualms or pangs of conscience to be interpreted as a "moral" imperative.

Appropriation on the basis of the majority of votes is group robbery (with preliminary conspiracy) using an especially dangerous type of weapon: the state. The very fact of such use of this powerful a means should, based on the general logic of things in legal matters, be evaluated as an aggravating factor, rather than as grounds for an indulgence for an action of this kind.

It is no accident that classical monotheism staunchly stands guard over private property, independently of whether the property owner is an appealing character in his own right, or not. The duty obtains of helping the poor (by giving them alms, tithes, and so on). But it obtains only before the Almighty (or as part of universal morality), not before the state.

\section{Fork in the Road: "Democracy of the Taxpayer" or "Democracy of Universal Suffrage" for Young Democracies in the $21^{\text {st }}$ Century}

When analyzing issues in public political life and the system of state organization in modern Russia, the opinion is often arrived at, that Russian citizens have no social or civil experience under conditions of democratic government and frequently enough cannot connect their own payment of taxes with steps undertaken by the agencies of the authorities in power.

Explanations of such conduct on the part of the Russians should be sought in the history of the Russian state: Mongol rule and the practice of paying dues and levies during the period of serfdom, the requisitioning of produce in the USSR, and so on. 
The citizens' notion of the authorities as a "sedentary bandit" also forms a corresponding attitude toward the tax system. The informal contract between citizens and the authorities is described as: "We pay you for leaving us alone."

The introduction of democratic institutions (elected power agencies and universal suffrage, freedom of expression and mass media, independence of the court system, and so on) in a social context of this kind is evaluated as an extension of personal freedoms, while the informal contract between citizens and the authorities is reformulated as: "We do not touch you - you do not touch us."

But state government based on democratic institutions took shape in a different historical context. Elected agencies of authority, suffrage, and the tax system are primarily linked to the accountability of the elected to those who elect them and pay for their work.

In the personal experience of every individual, such an attitude raises no doubt: for instance, when you choose a cab driver or a porter, your informal contract always presumes that for a certain amount of money you will be provided with a specific service, be driven somewhere, or have your luggage delivered where you want it. A more complex contract emerges in cases when choice is made by a number of people at once, such as when the residents of an apartment building hire a janitor.

Complexity of relations grows as the number of users who are interested in the choice being made goes up. For example, consider the situation if you want to pool your money and that of other investors for a joint investment. A number of people may agree among themselves personally, but additional formal and informal institutions are called for in order to coordinate the steps taken by thousands of investors.

The process of the emergence of democratic institutions is well explained from the point of view of the contract theory of the state, when citizens agree "to hire a politician" to provide certain services and agree on tax payments by means of which they will finance the work of this "politician."

The right to choose a "politician" is thus immediately bound up with the need to finance his activity, i.e., pay taxes, something bound up in turn with the possibility of controlling and making demands of the "politician." The greater the number of citizens involved in the process of choice making and financing, the more complex the mechanism of controlling the activity of the "politician."

We have already made a note of the significance of the principle of "No taxation without representation," which, by the late $18^{\text {th }}$ century, was taken by the American 
colonists as an "age-old freedom" - an unwritten but unchanging law. Obviously, given universal suffrage, securing approval for the decision to make payments for debts incurred during the War of Independence would have been extremely problematic. Yet this decision played an enormous role, primarily, a moral one, in fortifying trust put in the US authorities.

In Great Britain, the Parliament at a certain point turned into a means of controlling the royal family's spending by the creditors of the British court. Correspondingly, the right to choose members of Parliament was a prerogative enjoyed only by the richest citizens. Determining the identity of the persons enjoying the right to choose members of Parliament took formal shape as a voter qualifying requirement based on property: a set of minimal requirements which the electors had to fulfill.

In the course of a few centuries, the number of citizens of Great Britain enjoying the right to vote gradually grew as a result of both greater wellbeing of the citizens and reduction in the number of requirements. In the $20^{\text {th }}$ century, the right to vote was extended to all citizens, turning into universal suffrage. But formal universal suffrage is accompanied by an informal contract between citizens and government, which implies that citizens finance the activities of the government and control its effectiveness.

Universal suffrage in contemporary Russia is corroborated by the Constitution. The Constitution also corroborates the citizens' obligation to pay taxes. But what will happen if these constitutional norms are imposed on the following informal contract between citizens and the authorities: "We do not touch you - you do not touch us?" In such a case, the formal duty of paying taxes will constitute neither a social nor a moral imperative. Shirking taxes will then not be condemned by the citizens and will not become an amoral act. If taxes are seen as ransom from the "stationary bandit,"32 then shirking them becomes the "right" way to act, since taxes paid are a loss to the taxpayer, considering that the "stationary bandit" will spend these monies on some kind of personal needs of his own. At the same time, the state's inability effectively to collect taxes will be

\footnotetext{
${ }^{32}$ As Olson (Olson 2000) and V. Mau ("Nalogovaya sistema: Vernost’ordynskoy traditzii,” in Vedomosti №38, March 5, 2007, http://www.vedomosti.ru/newspaper/article.shtml?2007/03/05/121750), have shown, the economic significance of taxes in a non-democratic state differs radically from their purport under democracy. In this last case, the taxpayer covers, even if not quite voluntarily, the provision of public goods. Under the taxpayer's democracy, especially when tax brackets are confirmed each time a budget law is enacted (as was the case in $19^{\text {th }}$ century US), the level of consent was quite high, a datum poorly correlating with the democracies of today which feature universal suffrage. In a non-democratic country, by contrast, any payments to the state are practically unconnected with the volume or quality of public goods; they resemble tribute rather than tax, i.e., payment or ransom from violence in exchange for a temporarily deferred reprisal.
} 
the outcome of such an informal contract. Citizens will then be willing to "pay ransom" to the "bandit," striving to minimize the size of the tribute paid (by shirking taxes).

The right to choose definitely has a certain value for the voters, but this value is undermined by the principle of "We want nothing form you, just leave us alone." First of all, voters who do not value their right to vote particularly highly may in principle give it up, insofar as, for example, they value it less than the temporary costs of taking part in the elections. Second, voters who do not value their right to vote are prepared to "sell" it cheaply to politicians who promise them modest personal gains or improvements. This while the less voters value their right to vote, the "more cheaply" they will be prepared to sell their votes and the more easily they submit to promises and "baits" handed out before elections. Thereby voters who do not appreciate their right to vote open the way to populism and undermining of the political business cycle.

The formal duty of paying taxes is at the same time also the right to pay taxes. In order to understand why this is simultaneously a right, it suffices to glance at immigration laws and laws regulating issues of double taxation. Obtaining citizenship in a different country is, in a certain sense, obtaining such a right to pay taxes, obtaining in return access to the entire system of public institutions, system of social care, system of providing public goods, and more. Thus, for instance, immigration may also be interpreted from the point of view of wishing to obtain the right to pay taxes in a different country.

Similarly, the right to take part in elections at the same time also constitutes an informal obligation to take part in them. In obtaining the right to choose, voters thereby also assume the responsibility for the choice they make, just as a license to drive a motor vehicle always presumes driver responsibility for actions performed while driving. In directing au automobile, the driver is responsible for his or her actions. He or she must coordinate them with those around and obey both formal and informal traffic regulations. However, if traffic regulations are for the most part a set of formal rules and directives, and the obligation to follow them is supported by various formal institutions, then the duty to take part in elections is traditionally governed by informal imperatives. True enough, in many countries a system of compulsory participation in elections is in effect, based on fines, penalties, access to public goods, and so on. Forced participation in elections makes it possible to raise attendance, ${ }^{33}$ but does not solve the main question:

\footnotetext{
${ }^{33}$ The problem of populism and political-business cycle escalation remains in any case unsolved, even in case of compulsory elections attendance. Rather than a solution, the opposite is true: these problems are rendered more
} 
educating for responsibility. The duty of taking part in elections presumes not formal presence, but conscious responsibility for one's choice.

We begin to approach the thought that the right to vote and the duty to pay taxes are intimately bound up with each other; both are part of a more all-encompassing democratic institution. As has been noted previously, voting and tax rights and obligations are mutually connected by a system of accountability of the authorities and citizens' ability to control the agencies of power (Ill. 13.6).

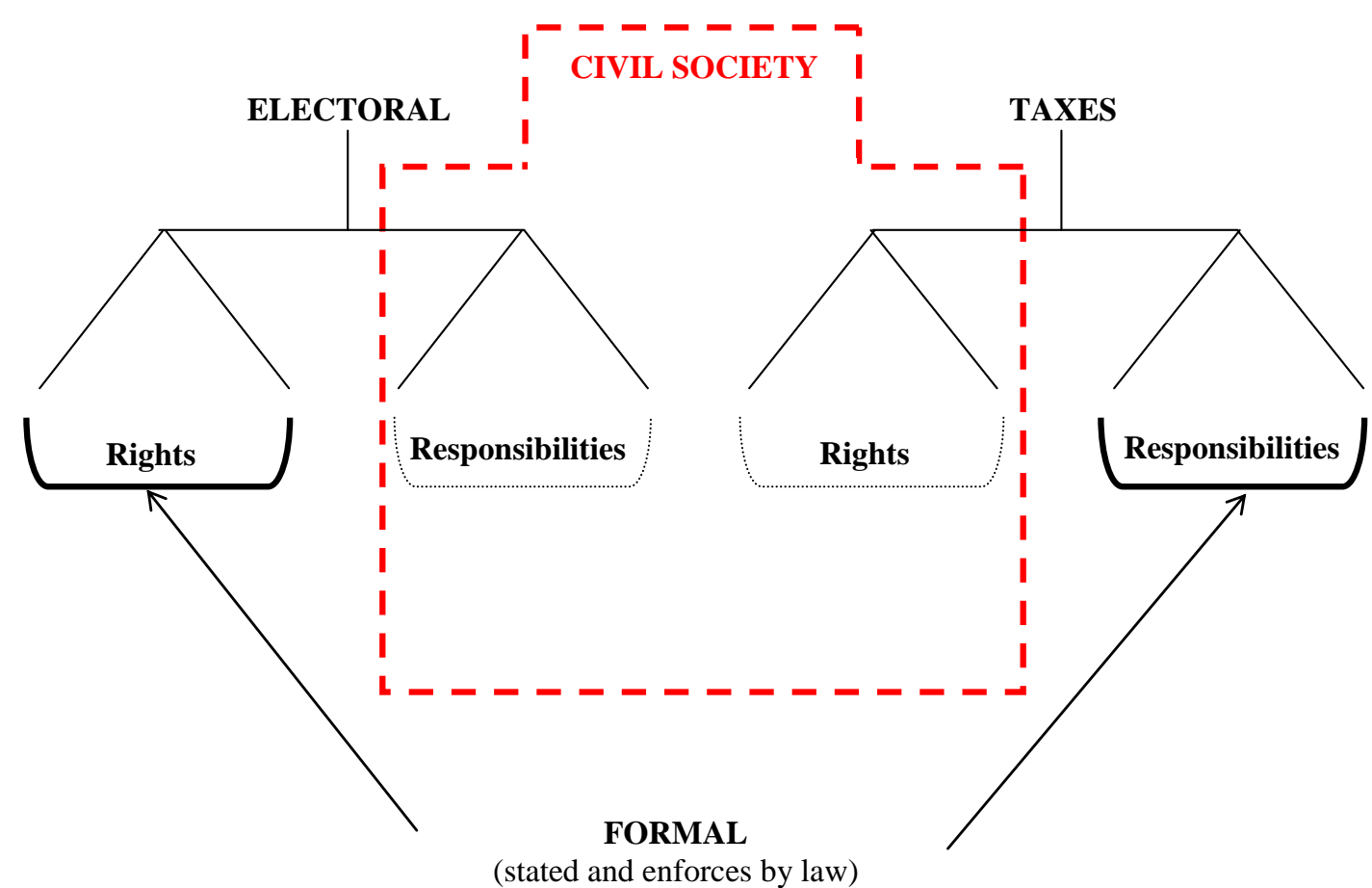

III. 13.6. Balance of Formal and Informal Civic Rights and Obligations

Thus, when citizens assume the obligation to pay taxes, they obtain the right of control and supervision of the effectiveness of these funds' deployment. This is exactly the same as the situation when citizens obtain the right to choose "politicians," and thereby accept the obligation to bear the responsibility for their choice (or the obligation to accept the choice made by the majority of their co-citizens).

acute with the appearance of voters not in the least appreciative of their right to vote, who would have stayed at home if not for the system of compulsory attendance. 
Controlling the activities undertaken by the state is an institution founded upon informal imperatives, traditions, and a mechanism of coercion. As it turns out, formal democratic institutions do not provide for the emergence of an effective democratic organization or management of society.

Applying such an analysis to the Russian realities of today, we see that by refusing their obligation to pay taxes, citizens also renounce their right to control agencies of power, while by depriving their voting rights of value, citizens refuse their obligations vis-a-vis controlling power and the authorities.

The upshot is that the institution of civic control of the authorities does not work. As before, citizens continue to pay taxes so as to "be left alone," giving their votes in elections (if they take part in elections at all) without thinking about the consequences.

How did the informal institution emerge, which connects citizens' voting rights and their tax obligations?

It should be noted that property and tax qualifying requirements constituted that formal institution which provided the link between tax and voting systems. But with time, the property voting qualifying requirement was lowered to the point where it made the entire population of the country qualify as voters. True enough, this process was accompanied by the genesis of immigration laws and limitations imposed upon the ability of citizens of other countries to be naturalized, where naturalization implies being virtually automatically granted the right to vote. Limiting immigration laws are, in part, a modern manifestation of the property voter qualifying requirement, which is being reincarnated as a voter qualifying requirement based on residence, citizenship, age, and sets of informal imperatives and regulations.

Let us state the problem: an institution needs to be created (a formal or informal one), which would complement the democratic institutions already borrowed from other sources and which is also requisite so as to provide the connection between the obligation to pay taxes and the right to vote. That is, the new institution is requisite so as to put to use the contractual model of the state, rather than the state constructed to serve the goals of the "stationary bandit."

Such an institution must at the same time raise the meaningful significance of the right to vote, developing civic responsibility during elections. Besides, it must facilitate an understanding of that taxes paid provide the right of citizens to control the use to which the tax monies are put. 
At a certain time in the past, the property voter qualifying requirement played a similar role. But a property voter qualifying requirement is only a private manifestation of the institution providing for the bond between the taxation and voting systems; most important, property voter qualifying requirements are discarded from sets of public imperatives and norms as a system in violation of the principle of equal rights.

A more effective means for forging a bond between payment of taxes and voting in elections is a tax voter qualifying requirement, which assigns the possibility of taking part in elections to individuals who have paid some certain tax total. An even more generalized voter/tax system may be proposed, where the right to vote would be granted to every taxpayer, but the taxpayers' votes would be bound up with the amount of tax money paid. Once such a principle is put to use, all other voter qualifying requirements having to do with residence, citizenship, age, and the rest, will become superfluous.

The simplest case of implementing such an approach is the universal voting mechanism. Given this, the result is not the number of votes cast for a certain party, but the quantity of tax money paid by the supporters of any one given party.

What we have described is an idealized contractual state system, in which citizens influence the decision making process with regard to tax use proportionately to their tax input. In this way, given conditions in which citizens' taxes are the principal source of state income, tax payment obligations and voting rights for the citizens may be so intimately connected that a situation becomes feasible, in which tax coercion is no longer the principal stimulus for the process of tax payment, but elections become an indelible part of the mechanism of managing one's own paid taxes.

Decisions of this kind may be up for discussion primarily in young democracies, or in transition countries restoring their democratic institutions after a period of authoritarian (totalitarian) rule. This is a must in view of the principle noted earlier of the need for the most radical solutions for countries which had a late start.

Such an approach is justified from the moral point of view. As a matter of fact, when a voter qualifying requirement is introduced (in effect, the discussion concerning the usefulness of "voting proportionately to taxes paid" can practically be directed at establishing a bond between taxation and representation), nobody takes anything away from anyone in the countries in question. Given an authoritarian (let alone a totalitarian) regime, there is no making of choices. Pretending to recognize it is almost as amoral as recognizing "threesomes" in "court" and "respecting their decisions" (this did not occur even to the communists themselves). The right of tax-NON-payers to vote poses a threat 
for any country, but it is especially dangerous for transition economies with weak, young democracies. Confirmation of this claim may be found in a survey of the electoral history of post-socialist countries and a study of the link between electoral preferences and economic growth.

In Estonia, a voter qualifying requirement was introduced based on the principle of inherited citizenship in the inter-war independent republic. The requirement largely eliminated workers of enterprises constructed after World War II based on the decision of the Soviet authorities and the labor force imported from abroad. These enterprises had objectively few chances to secure a niche for themselves in the market; a voter qualifying requirement of this kind undermined the positions of leftist parties opposed to market reforms. In essence, competition during elections was real between centrist, moderately leftist liberal forces (from the Party of the center and further to the right 34 ), and rigidly conservative and pro-market parties (Party of the Fatherland, Reforms Party, and so on). Subsequently, anti-market parties (communist or leftist nationalistic ones, such as the Communist Party of the Russian Federation, "Greater Rumania," or the Liberal Democratic Party of Russia) were simply not represented in parliament there.

It should be stressed that the voter qualifying requirement introduced in Estonia is less effective from the point of view of long-term political-economic influence than a voter qualifying requirement based on payment of taxes. Even so, the legislation and law-enforcing practices are then much more "friendly" toward the market than in countries where there was no voter qualifying requirement and in which positions of anti-market radicals continue to remain strong (Lithuania and Hungary, to say nothing of Rumania, Moldova, Bulgaria, or Ukraine).

Limitations of this kind, by providing for the emergence of the best possible promarket institutions, facilitate long-term economic growth, raising ever new groups of taxpayers who automatically (based on the database of existing agencies, possibly even without officials' direct involvement) become voters with a gradual withering away of

\footnotetext{
${ }^{34}$ At the same time, the large-sized leftist liberal Party of the Center had an insignificant impact on the decision making, especially when compared with rightist parties similar to it in average level of electoral support. These last have a total of 35 to $50 \%$ of the votes; see the sites of the Central Voting Commission of Estonia at http://www.vvk.ee/ and "Elections and Parties in Europe": http://www.parties-and-elections.de/estonia2.html.
} 
the difference between the notions of "citizen" and "voter." As the circle of taxpayer voters widens, healthy stimuli emerge for cooperation and taking each other's interests into account. As the circle of voters who are clients of the budget grows, motives become stronger for making the transition from the taxpayer category into that of the budget net recipients. Contradictions between the aims of taxpayers and tax recipients are objectively stronger than those among different groups of taxpayers, portending serious conflicts in the long term (as a result of near total absence of shared interests).

\section{The Road Back: Those Who Do Not Pay Taxes - Do Not Vote}

The idea that the state is not the lord but the servant and that the servant who does not manage to handle his duties, is nasty, and finagles ever higher pay, can and should be dismissed, was the beginning and the source of revolutions which led to the creation of the first Rule of Law democracies.

Remembering historical precedents, the citizen and voter described above, like the American colonist in 1776, can rightfully ask the question: is it not time to employ a different state instead of the one a priori not fulfilling its obligations?

A state in which the court system is constructed not for the purpose of protecting the interests of a handful of lawyers, but based on reliable functional models. Where dismissal from one's position will take place not by decision of a tightly knit circle of senior colleagues, but of the qualified majority of deputies of the Federal Assembly following a complex, extensive procedure, ${ }^{35}$ a procedure which - as practice has shown is really reproducible a bare few times per century. This last means that adherence to is capable of protecting a judge from the fury of the mob, as well as from the revenge of colleagues.

The state in which nobody can be forced to pay from his own pocket for the microphone to be used by a reporter with whom the payer does not agree, but rather the journalist will need to earn the right to a microphone from the point of view of his fellow opinion holders; journalists will also need to defend their views in free debate with their colleagues, whose microphone has been paid for by opponents. All this without having

\footnotetext{
${ }^{35}$ Similar to the procedure for dismissing the state controller in Israel; see Article 13 of the Principal Law Concerning State Controllers.
} 
the option of summoning an obedient police force and gagging the critics, accusing them of "incitement to mutiny" or "provocation of hatred."

A state in which all the political parties and leaders finding more important tasks to concern themselves with than protecting the life, liberty, property, and dignity of the citizens, would be deprived of the opportunity not just to claim authority, but also to be considered as legitimate opposition.

The model operative in most modern democratic states of ochlocratic-bureaucratic government ${ }^{36}$ is outliving its day, encountering challenges which it cannot meet. This involves crisis of the pension system, social protection, demographic issues, immigration coupled with increasing political complications, and more. Essential reforms are blocked by interest groups leaning on "voting parasites." 37

The resulting situation, sadly enough, is not new; it has been described as far back as by Aristotle. For the great Greek thinker contrasting mob rule to democracy, Pericles was not a "Moses in the reeds"; Aristotle could well imagine the problems connected with the rule of a crowd of "parasites." Recipients of pensions from the treasury of the Delian League, sophists and the rest... were for him the historically recent past.

Today the idea of refusing universal suffrage finds ever more supporters. Thus, in Israel, elections to the $18^{\text {th }}$ Knesset saw $13 \%$ of the vote given to a party which called for granting the right to vote only to those swearing fidelity to the state and performing military or civil duty.

History has not seen many cases of rescinding of political privileges. Even so, such cases have occurred in reality. For instance, the same legislative reforms which destroyed the "rotten spots," also delivered powerful blows against groups which had been influential up until that time. By releasing prices, Gaydar with a single blow dismantled what had appeared powerful interest groups of the former Soviet "trade."

The question thus concerns the political will of the reformers. In order to introduce such decisive reforms, it is insufficient to understand the economic infeasibility of preserving the "bouquet" of social and political privileges. An understanding of the amorality of such privileges is called for; an understanding of the damage which they cause to their beneficiaries, similar to what is done by the plethora of natural special

\footnotetext{
${ }^{36}$ Or "universal suffrage democracy," or, as indicated by the dynamics of the court system and law enforcement agencies, the distortion of media markets, using the education system for propaganda, and other means used by such authorities to blur the guarantees of basic rights. This rule fits perfectly the definition of "illiberal democracy."

${ }^{37}$ Their circle is certainly much smaller than the nefarious " $47 \%$ Romney"; even so, it is quite extensive, even in the US.
} 
discounts. The privilege recipients are taken advantage of by the rich and the powerful, who use them to enrich themselves even further and definitively rid themselves of the persistent control of voters, opposition, and the independent press.

In addition to the instance cited above, when the population of Estonia calmly accepted the introduction of voter qualifying requirements in the 1990s, ${ }^{38}$ immigrant adaptation experience in the US should also be made a note of. Arriving in the late $19^{\text {th }}$ century via New York, the new immigrants were at first poorly adapted, tending to support leftist extremist groups for years after receiving the right to vote.

Even in 1920, the country-wide (US) average was 1-3\% voting for the socialists, about $6 \%$ in California, and about $8 \%$ in New York (in presidential elections).

Of the 43 districts, during elections to Congress, in three districts (albeit the smallest in terms of number of voters), the extreme left received more than one-third of the vote, including winning in one (!); they also obtained more than $15 \%$ of the vote in two others.

In total country-wide, in the early $20^{\text {th }}$ century, leftist groups got up to $6 \%$ in the presidential elections (U. Debbs, 1912) and up to $9.6 \%$ in elections to the Senate (1910), as well as up to $6.4 \%$ in elections to the House of Representatives (1912). They thereafter lost support (even in 1932, with the Great Depression at its height, socialists and communists together obtained $1.63 \%$ in elections to Congress and not a single seat; $2.57 \%$ in the presidential elections, and, thus, not a single elector; the leftist farmers' party - i.e., in the regional center of the powerful crisis, but not of immigration - thanks to population density, obtained 5 seats with $0.88 \%$ of the vote in the same year, with 3 seats in 1934, and none in subsequent years). Thereafter, all leftists marginalized at breakneck speed to fractions of a percent (see the electoral statistics on the site of the Clerk's Office at the House of Representatives; Tanin-Lvov 2000).

Clearly enough, powerful coalitions of supporters of the status quo, headed by interested state employees, will do everything they can to block such reforms. Who, then,

\footnotetext{
${ }^{38}$ The same as in Latvia.
} 
is capable of putting forth such a demand for the reforms, which will be able to outweigh these powerful stimuli of the opponents?

Paradoxically enough, it seems that it is precisely the supporters of the welfare state the universal suffrage democracy - that will do everything it takes to ensure the emergence of a coalition sufficiently powerful and motivated so as to do what today appears to be the incredible.

We have already written above about the tendency to enlarge the circle of budget and state clients (Chapter 3), and about "inviting" foreign reinforcements for homeland clients (Chapter 7). The tendency is natural for the individual to help "one's own," similar to an unwillingness to help strangers. As the distance grows, the readiness weakens. Even relatives or friends risk losing support if they lay claim to it constantly and begin to see it as their due.

However, as noted in Chapter 3, interest groups and the state are still successful in delegating a multitude of burdens and costs to the population. Collective action by the taxpayers in response is restrained by means of tax policies pertaining to the so called relatives.

But certainty that the capacity to expand the circle of recipients is infinite raises some doubt. ${ }^{39}$ In many countries, the share of the "donors" is dropping, while the burden placed upon them has been growing for more than just one single generation in the past. This buurden is, accordingly, seen as being long-term. That, in turn, means that persons with individual discount coefficients close to one (who see the welfare of their grandchildren and great-grandchildren almost as their personal own), the motivation for bearing considerable one-time costs can reach unusually high values. The coordinating effect of the high costs incurred by such agents can lead to rapid growth in the coalition's makeup.

Growth in the demand for new rightist parties ${ }^{40}$ which combine nationalistic ("antiimmigration") agenda with economic (classical) liberalism may be just the first sign of the gestation of such coalitions. Independently of their failures or successes, the example of new taxpayer coalitions against "alien" recipients and the welfare state has in the long term all it takes to enjoy wide circulation and acceptance.

\footnotetext{
${ }^{39}$ Then again, the institutions described in Chapters 1 and 2 which serve to repress freedom of expression by means of political correctness, legislation concerning Hate Speech, and so on, are a reaction to such unwillingness - a reaction constructed upon the hope of solving the problem by repression.

${ }^{40}$ The Progress Party in Norway, or the Swiss National Party.
} 
Taxpayers are clearly not inclined to believe themselves to be adequately represented in parliament. This part of the population comprises a minority, but a minority significant enough to assume power if claims to power are indeed put forth.

Besides, the alternative to a "revolution of the taxpayer" is the continued erosion of democratic institutions. The logical conclusion of this process is to cease functioning, or the dismantling of Rule of Law democracy. Decentralized society requires loyalty and responsibility of a large number of its members. In the absence of "sufficient" supply (with the lowering of the share of responsible citizens below a certain level), such a system becomes vulnerable to attack by "Olsonian" bandits both from the without and from the within.

Examples of instability in "republics without republicans" and without "republican valor" are rife in history; they are numerous enough to call for serious consideration. They are plentiful in European history, as well as in the history of Russia (from the fall of Great Novgorod, to the indifference of the majority of Russian electors).

The coupling together of the collapse of some democratic regimes and the survival of others, albeit in a new (the well forgotten old) form, is seen as a thoroughly long-term prognosis for Europe if the tendencies presently observable are maintained.

Most likely, the restoration of the taxpayer's democracy will not lead to any largescale reduction in the numbers of voters. During the 20-30 years since the beginning of reforms, up to $90 \%$ and more of the adult population will have voting privileges obtained based on universal criteria (i.e., by right ${ }^{41}$ ). However, during the time required by the reform, a new social imperative attitude will have had a chance to emerge: to be economically independent is fine, while to be a state budget worker is rather bad (a certain comfort paid for by voter privileges). For a healthy, not aged adult, and even for a middle-aged person who is not handicapped, to be a recipient of social aid is a disgrace.

\section{References}

Acemoglu D., Robinson J.A. Economic Origins of Dictatorship and Democracy. Cambridge University Press, 2006.

\footnotetext{
${ }^{41}$ As far as universality of criteria or accessibility for the overwhelming majority is concerned, democracy of the taxpayer can well become an example of universal suffrage. The right to vote in it will be "universal" in the sense that everyone will be capable of obtaining this right by the time of the next scheduled elections.
} 
Adams J. Defence of the Constitutions of the United States. Vol. 1. L.: Minted For C. Dilly, in the Poultry, 1787-1788.

Aidt T.S., Dutta J., Loukoianova E. "Democracy comes to Europe: Franchise extension and fiscal outcomes 1830-1938" // European Economic Review. 2006. Vol. 50. N 2.

Alvarez, Michael, Cheibub José Antonio, Limongi Fernando and Przeworski Adam. 1996. "Classifying political regimes". Studies in Comparative International Development 31 (Summer): 1-37

Aristotle. Politics: A Treatise on Government. Guttenberg Project. http://www.gutenberg.org/etext/6762.

Barro R.J. Are government bonds net wealth? // Journal of Political Economy. 1974. $\mathrm{N} 82$.

Bastiat Frédéric, Best of Bastiat "The Law" Indianapolis: Liberty Fund, 2013 (online Liberty Library)

Beard Ch.A. An Economic Interpretation of the Constitution of the United States. N.Y.: The Free Press (Simon \& Schuster), (1913) 1986.

Boix Carles "Democracy, Development, and the Public Sector" American Journal of Political Science Vol. 45 \#1 January 2001 pp. 1-17

Cobden R., "On State Production Plants and Workshops," \#Vol. I, Finance, Speech 7 .made by R. Cobden in the English Parliament, on July 22, 1864. EconLib, Volume I Finance Speech VII. House of Commons , July 22, 1864 http://www.econlib.org/library/YPDBooks/Cobden/cbdSPP33.html

Dahl R. A. "Polyarchy: Participation and Opposition" Yale University Press, 1972

Dahl R. A., "On Democracy" Yale University Press, 2000

De Soto Hernando The Mystery of Capital: Why Capitalism Triumphs in the West and Fails Everywhere Else Basic Books 2003.

De Soto Hernando The Other Path: The Economic Answer to Terrorism Basic Books; 2002

Downs A. An Economic Theory of Democracy. N.Y.: Harper and Brothers, 1957.

Feiglin M. "Innocent civilians" (in collected articles publication "The War of Dreams" pp. 325-330)

Freedom House 2008. Freedom in the World Survey Methodology. http://www.freedomhouse.org/template.cfm?page=351\&ana_page=341\&year=2008.

Friedman Milton, Friedman Rose Free to Choose: A Personal Statement. Mariner Books 1990.

Funk Patricia, Gathmann Christina "What Women Want: Suffrage, Gender Gaps in Voter Preferences and Government Expenditures" SITE - Stockholm School of Economics Stanford University (Draft): July 2006

Gaidar Yegor "Collapse of an Empire: Lessons for Modern Russia" Brookings Institution Press October 17, 2007

Gaidar Yegor "Russia: A Long View" The MIT Press October 12, 2012

Gallup Inc., Результаты опросов по группам населения по итогам выборов Президента США 2004, 2008 и 2012 гг. Службой Гэллапа. http://www.gallup.com/poll/154577/Election-2012-Weekly-Demographic-Data.aspx; http://www.gallup.com/poll/112132/Election-Polls-Vote-Groups-2008.aspx; http://www.gallup.com/poll/13957/How-Americans-Voted.aspx (2004).

Gwartney J., Holcombe R., Lawson R. The Scope of Government and the Wealth of the Nations // Cato Journal. 1998. Vol. 18. N 2.

Hall D. "Why wee need public spending" PSIRU University of Greenwich, October 2010 
Hallini D.C., Mancini P. Comparing Media Systems. Three models of Media and

Politics. Cambridge University Press, 2004.

Lal D. "Unintended Consequences" MIT Press, 2001

Maddison A. Monitoring the World Economy 1820-1992. Paris: OECD, 1995.

Magnet $M$. The Dream and Nightmare: The Sixteis Legacy of the Underclass. N.Y.: Quill/Mirrow, 1993.

Mau V., F.Arias King, K.Yanovskiy et al., «Instituty zakrytyh demokratiy : popytka sravnitelnogo analyza » (Closed Democracies institutions: comparative studies' approaches) IET, wp\#107, 2007

Mau V., S.Zhavoronkov, D.Maslov, K.Yanovskiy et al « Institucionalnye predposylki sovremennogo ekonomicheskogo rosta », IET, wp\# 106r (Institutional preconditions of the modern economic growth) , 2007.

Mau V., Zhavoronkov S., Yanovskiy K. et al. «Importirovannye instituty v stranah s perehodnoy ekonomikoy: effektivnost i izderjki» (Imported institutions in the Transitional countries : efficiency and costs) 2003 Moscow, IET, wp\#68.

Melanie Ph. Yes Big Brother Britain menace. The irony civil liberties lobby blame http://www.dailymail.co.uk/debate/article-1158337/MELANIE-PHILLIPS-Yes-Big-

Brother-Britain-menace-The-irony-civil-liberties-lobby-blame.html.

Mitchell B. International Historical Statistics 1750-2005: (International Historical Statistics Africa, Asia and Oceania). L., Palgrave, 2007.

Niskanen W. Bureaucracy and Representative Government. Chicago: Aldine-Altherton, 1971.

Niskanen W. Welfare and the Culture of Poverty // Cato Journal. Vol. 16. N 1. 1998.

Noelle-Neumann Elisabeth The Spiral of Silence: Public Opinion--Our Social Skin

University Of Chicago Press; 1 edition November 15, 1993

Nordhaus W. The Political Business Cycle // Review of Economic Studies. 42. April 1975.

North D.C. Understanding Economic Change // Transforming Post-Communist Political Economies / J.M. Nelson, Ch. Tilly, Lee Walker, eds. Washington D.C.: National Academy Press, 1997.

North Douglass C., Wallis John J., Weingast Barry R. "Violence and Social Orders"

Cambridge University Press, 2009

OECD in Figures 2007 - OECD (C) 2007 - ISBN 9789264034549

Olson M. Power And Prosperity: Outgrowing Communist And Capitalist Dictatorships Basic Books, 2000

Olson M. The Hidden Path to a Successful Economy // The Emergence of Market Economics in Eastern Europe / C. Clague \& G. Rausser (eds.) Blackwell, 1992.

Olson M. The Logic of Collective Action: Public Goods and the Theory of Groups. Harvard University Press; 1971

Olson M. The Rise and Decline of Nations: Economic Growth, Stagflation, and Social Rigidities Yale University Press 1984

Olson W. The Rule of Lawyers How the New Litigation Elite Threatens America's Rule of Law. Truman Talley Books, 2003.

Peregudov S.P. Thatcher $i$ thatcherizm Moscow Nauka publishers, 1996 (Thatcher and Thatcherism, written in Russian). 
Phillips M. Yes Big Brother Britain Menace. The Irony Civil Liberties Lobby Blame // Daily Mail. 2 March 2009.

Polishchuk L., Savvateev A. Spontaneous (non)emergence of property rights // Economics of Transition. Vol. 12 (1). 2004.

Przeworski A., "Democracy and the Limits of Self-Government" Cambridge University Press, 2010

Przeworski A., Alvarez M.E, Cheibub J.A. et al. Democracy and Development. Political Institutions and Well-Being in the World 1950-1990. Cambridge University Press, 2000.

Przeworski A., Alvarez M.E, Cheibub J.A. et al. Democracy and Development: Political Institutions and Well-Being in the World 1950-2000. Cambridge University Press, 2000.

Przeworski, Adam. 2007. "Conquered or Granted? A History of Suffrage Extensions."

New York University http://politics.as.nyu.edu/docs/IO/2800/suffrage_ext.pdf

Sharansky Natan and Dermer "The Case for Democracy The Power of Freedom to Overcome Tyranny and Terror" PublicAffairs (February 7, 2006)

Shleifer A., Glaeser E., La Porta R., Lypez de Silanes, F. Do Institutions Cause Growth // Journal of Economic Growth 9:271-303. 2004.

Smith Vernon L. "Experiments with a Decentralized Mechanism for Public Good

Decisions" The American Economic Review, Vol. 70, No. 4 (Sep., 1980), pp. 584-599.

Stigler G.J. (1970), Director's Law of Public Income Redistribution, Journal of Law and Economics 13: 1-10.

Sweetman B. Laser Weapons Gain Momentum // Aviation Week. 2008. Apr. 21.

Tavares Jose, Wacziarg Romain "How democracy affects growth" // European

Economic Review 45 (2001) 1341 - 1378

Tilly Charles "Democracy" Cambridge University Press; 2007.

Tocqueville Alexis de "Democracy in America." Borgo Pr; Collector's Edition 1991

Yanovskiy K. Zhavoronkov S., Kudryavtseva E., Reform of the Social Sphere: Institutional Barriers at the Regional Level 2007. Consortium for Economic $\begin{array}{llll}\text { Policy Research and } 2007 & \end{array}$ http://papers.ssrn.com/sol3/papers.cfm?abstract_id=2125180

Yanovskiy K., Cherny D., Rusakova E. et al., "Crisis instituta semji v postindustrialnom obshestve: analiz prichin I vozmozhnosty preodoleniya" ("Crisis of the Family institution in the Post-Industrial Society: Analysis of Causes and ways for overcoming") (Moscow, IET, wp\#112, 2008)

Yanovskiy K., S.Shulgin "Zolotaya seredina v borbe s terrorom" (The golden mean in the struggle against terrorism) // Obshestvennye nauki I sovremennost (Social Sciences and Modernity), \#5, 2007 Academy of Science of Russia pp. 46-59

Yanovskiy K., Shulgin S., "Instituty, Demokratia I ekonomicheskiy rost: test 180-letnego razvitiya" (The Institutions, Democracy and Economic Growth: 180-years economic development test)" //"Ekonomicheskaya politika" №3 June 2008, pp. 57-75 ("Institutions, Democracy and Growth in the very Long Run" (forthcoming, Acta Oeconomica 2012) http://papers.ssrn.com/sol3/papers.cfm?abstract_id=2236320 )

Yanovskiy K., Shulgin S., Zatcoveckiy Ilia et al., «Politico-economic Aspects of Combat with Terrorism" IET, 2005 WP\#82-r , 2005. 
Zatkoveckiy I., Shulgin S. Yanovskiy K., "Electoralnoe povedenie kak reakcia na ugrozu terrora" (Electoral behavior as the terror's danger reaction) // Obshestvennye nauki I sovremennost (Social Sciences and Modernity), \#5, 2009 Academy of Science of Russia pp. 60-70.

Арон Л. Демократия, избыток рабочей силы и политика переходной экономики: Доклад на конференции «Экономический рост: после коммунизма». Москва, 2002 // Политика в регионах: губернаторы и группы влияния. М., 2002.

Лагунина И., Чернеикий В. Почему испанское общество возвращается к церкви // Радиостанция «Свобода», «Время и мир», 30 сентября 2008 г.

Мельянцев В. Восток и Запад во втором тысячелетии: экономика, история и современность. М.: МГУ, 1996.

Танин-Львов А. Выборы во всем мире: Электоральная свобода и общественный прогресс: энциклопедический справочник. М.: Российская политическая энциклопедия (РОССПЭН), 2000.

\section{Additional Internet sources references}

http://www.dcboee.org/election_info/election_results/election_result_new/results_final_g en.asp?prev=0\&electionid=2\&result_type $=1$. Washington DC Board of Elections and Ethics.

http://www.cbo.gov/budget/data/historical.xls. Congressional Budget Office.

http://research.eco5.com/?parent=2\&subparent=22. US Governmental finances History references collection

http://www.treasurydirect.gov/govt/reports/pd/histdebt/histdebt_histo4.htm. Federal Treasury USA

http://www.whitehouse.gov/omb/budget/fy2009/. Office of Management and Budget, 2008; 2009. Budgets Historical Tables.

http://www.whitehouse.gov/infocus/budget/2009/index.html.

http://eh.net/hmit/.

http://www.bea.gov/. U.S. Department of Commerce Bureau of Economic Analysis

http://www.gpoaccess.gov/eop/download.html..

http://clerk.house.gov/member_info/electionInfo/index.html. 